QUARTERLY PROGRESS REPORT

RESEARCH AND DEVELOPMENT ACTIVITIES

WASTE FIXATION PROGRAM

JULY THROUGH SEPTEMBER 1974

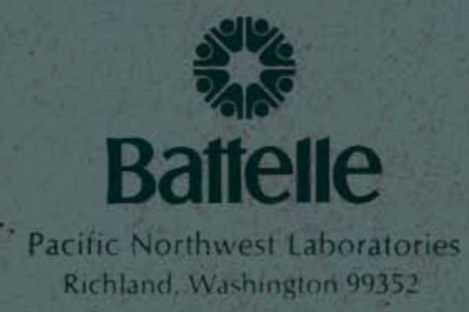

NOVEMBER 1974

Prepared for the U.S. Atomic Energy

Commission under Contract AT(45-1): 1830

亦 
NOTICE

This report was prepared as an account of work sponsored by the United States Government Neither the United States nor the United States Atomic Energy Commission, nor any of their employees, nor any of their contractors, subcontractors, or thier employees, makes any warranty, express or implied, or assumes any legal liability or responsibility for the accuracy, completeness or usefulness of any information, apparatus, product or process disclosed, or represents that its use would not infringe privately owned rights.

PACIFIC NORTHWEST LABORATORY operated by

BATTELLE

for the

U.S. ATOMIC ENERGY COMMISSION Under Contract AT(45-1)-1830

Printed in the United States of Americ

Available from

National Technical Information Service

U.S. Department of Commerce

5285 Port Royal Road

Springfield, Virginia 22151

Price: Printed Copy \$5.45; Microtische \$2.25 
BNWL -1871

UC -70

Waste Disposal

and Processing

\author{
QUARTERLY PROGRESS REPORT \\ RESEARCH AND DEVELOPMENT ACTIVITIES \\ WASTE FIXATION PROGRAM \\ JULY THROUGH SEPTEMBER 1974
}

\author{
Compiled by \\ J. L. McElroy \\ Nuclear Waste Technology Department
}

November 1974

BATTELLE

PACIFIC NORTHWEST LABORATORIES

RICHLAND, WASHINGTON 99352 


\section{TABLE OF CONTENTS}

LIST OF FIGURES

LIST OF TABLES

INTRODUCTION

SUMMARY

COMMERC IAL WASTE FIXATION .

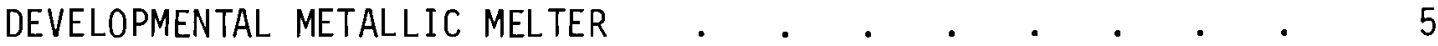

JOULE HEATED CERAMIC MELTER.$\quad \cdot \quad \cdot \quad \cdot \quad \cdot \quad \cdot \quad \cdot \quad \cdot \quad \cdot 10$

IN-CAN MELTING

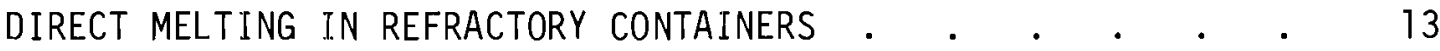

DEVELOPMENTAL SPRAY CALCINER . • • • • • • • • • • • 15

WIPED FILM EVAPORATOR $. \quad . \quad . \quad . \quad . \quad . \quad . \quad . \quad . \quad . \quad 17$

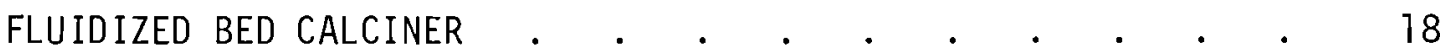

PRODUCT CHARACTERIZATION . . . . . . . . . . . . . . . . . 21

COMMERCIAL RADIOACTIVE WASTE COMPOSITION USED IN

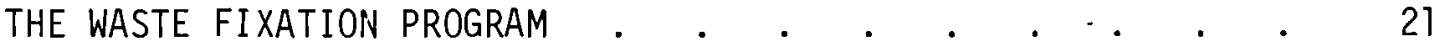

STORED ENERGY MEASUREMENTS . . . . . . . . . . . . . 25

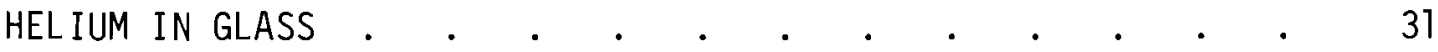

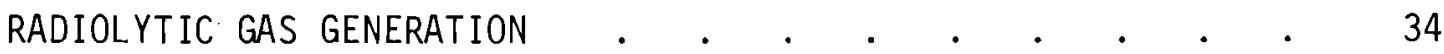

WASTE VAPORIZATION STUDIES . . . . . . . . . . . . . • 34

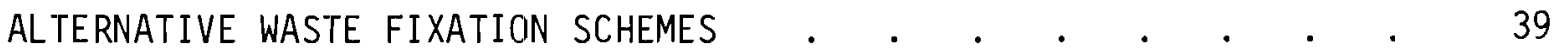

GLASS SINTERING

CARBON AND SIC COATED WASTE PARTICLES . . . . . . . . . 44

VITREOUS CARBON WASTE CONTAINMENT . . . . . . . . . . 47

ADVANCED WASTE FORMS RESEARCH AND DEVELOPMENT — • • . . . 49

Characterization of Standard PW-4b Calcine . . . . 50

Matrix Isolation of $\mathrm{PW}-4 \mathrm{~b}$ in $\mathrm{SiO}_{2}$. . . . . . . 51

Supercalcine . . . . . . . . . . . . 53

Crystal Chemical Background for

Supercalcine Formulations . . . . . . . . . 56

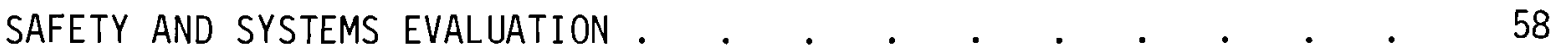

SAFETY AND SYSTEMS EVALUATION

METHODOLOGY FOR FAULT TREE EVALUATION

IMPACT TESTING OF GLASS IN SIMULATED WASTE CANISTERS . • • 61

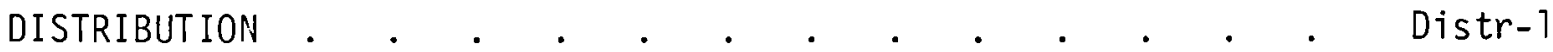




\section{LIST OF FIGURES}

1 12x Photomicrograph of Cross-Section of Melter Drain Tube Showing Extent of Corrosion after 445 Hours of Use

2 Ceramic Melter, Cross-Sectional Views . . . . . . . . 11

3 Process Flow for the Fluidized Bed Calciner System . . . . 18

4 Calciner Vessel and Filter Chamber . . . . . . . . . 19

5 Typical Scan for Stored Energy Measurements . . . . . . 27

6 Energy Release Rate - Specimen SEN-4 . . . . . . . . . 28

7 Energy Release Rate - Specimen SEN-5 . . . . . . . . . . . 28

8 Energy Release Rate - Specimen SEN-7 . . . . . . . . . 29

9 Energy Release Rate - Specimen SEN-9 . . . . . . . . . 29

10 Energy Release Rate - Specimen A-3 . . . . . . . . 30

11 Helium Release from a Sample Equilibrated at $540^{\circ} \mathrm{C}$ for 24 Hours with 680 Torr Helium . . . . . . . . 32

12 Vitreous and Devitrified $\left(5\right.$ days $\left.-750^{\circ} \mathrm{C}\right) \mathrm{X}$-ray Diffraction Patterns for Glass 72-68 . . . . . . . . . . . . . 33

13 Zinc Orthosilicate Diffraction Intensity in Glass 72-68, Plotted as Intensity Versus Time at $750^{\circ} \mathrm{C}$. . $_{0} . \quad . \quad . \quad 33$

14 Vaporization of $73-167$ Glass at $1200^{\circ} \mathrm{C}$ in Dry Air . . . . 36

15 Vaporization of $73-167 \mathrm{Glass}$ at $1000^{\circ} \mathrm{C}$ in Dry Air . . . . 36

16 Vaporization of $73-167$ Glass at $1200^{\circ} \mathrm{C}$ in Dry Air . . . . 37

17 Vaporization of $73-167$ Glass at $1000^{\circ} \mathrm{C}$ in Dry Air . . . . 37

18 Weight Loss from Glass 73-167 in 10 Hours as a Function of Moisture . . . . . . . . . . . . . . . . 38

19 Sintering Curves for PW-4b-2 and 73-1 Mixtures . . . . . 40

20 100x Photomicrograph of a Sintered Pellet Containing 30\% PW-4b-2 Calcine and 70\% 73-1 Frit . . . . . . . 44 
21 PyC Coated Waste Particles Encapsulated in Al Matrix,

a) $10 \mathrm{X}$, b) $50 \mathrm{X}, \mathrm{c}) 50 \mathrm{X}$ Edge Location Showing Reaction of

Al with Stainless Steel Wall . . . . . . . . . . 45

22 Interim Surface Storage Fault Tree (Activity No. 9) . . . 59

\section{LIST OF TABLES}

1 Melter Capacity and Power Requirements . . . . . . . . . 9

2 Physical Properties of Reference Calcines . . . . . . . . 15

3 Results of Sieve Analysis of Reference Calcines . . . . . 15

4 Composition of Waste Solutions Used in Waste Fixation

Program (Supplement No. 1) . . . . . . . . . . . 23

5 Summary of Stored Energy Measurements . . . . . . . . . . 26

6 Effect of Frit Particle Size on Sintered Density . . . . . 39

7 Effect of Pressing Pressure on Sintered Density . . . . . 42

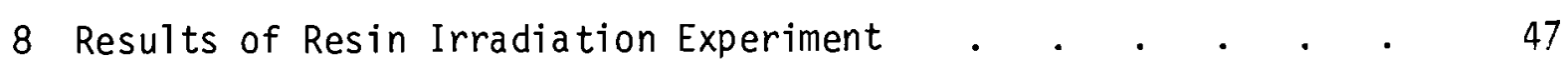

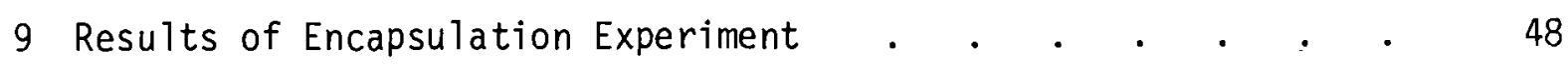

10 Carbonization of Resin Containing Three Simulated Wastes . . 49

11 Atomic Concentrations in Standard PW-4b Calcine . . . . 50

12 PW-4b/Hybrid Matrix Results . . . . . . . . . . 53 


\author{
QUARTERLY PROGRESS REPORT \\ RESEARCH AND DEVELOPMENT ACTIVITIES \\ WASTE FIXATION PROGRAM \\ JULY THROUGH SEPTEMBER 1974
}

\title{
INTRODUCTION
}

This progress report is the eighth in a series that presents research and development activities in the field of radioactive waste fixation. Previous progress reports were BNWL-1699, 1741, 1761, 1788, 1809, and 1841 .

\section{SUMMARY}

Three melting concepts are currently being evaluated for use in converting waste calcine to glass. These are a resistance heated metallic melter, a joule heated (electric) ceramic melter, and in-can melting. The metallic melter is made of Incone1-690; however, tests are under way to locate a better material. One possibility is an Inconel-690 weld overlay, since corrosion experience with the Incone 1-690 melter indicates moderate attack to the base metal but essentially no attack at the welds. Several metallic melter runs were completed to 1) test coupling of the melter to a wiped film evaporator to evaluate feeding slurry to the melter, 2) determine the maximum melt viscosity that could be drained from the freeze valve, and 3 ) produce five large glass castings for annealing studies.

A ceramic melter has been designed and fabricated to melt glass composition (72-68) at approximately $1200^{\circ} \mathrm{C}$. A melter startup technique has been developed that employs sacrificial resistance wires and starter elements that rapidly corrode in molten glass at elevated temperatures.

In-can melting has been demonstrated on a laboratory scale at 950 and $1000^{\circ} \mathrm{C}$. Calcine and glass frit additives are added batch wise or continuously to the waste storage canister and are melted directly in the can. In one test a $70 \%$ solids slurry was successfully melted by this technique. 
The spray calciner is being modified to improve the atomizing nozzle and to improve calcine scale removal from the wal1. $B_{4} C$ inserts and $96 \%$ alumina air caps for the feed atomizing nozzle are being tested as replacements for stainless steel parts which erode and lead to shortened nozzle life. Thermal cycling is the area of greatest concern with the ceramic parts; however, in tests thus far the nozzles have not been affected when cycled from $25^{\circ} \mathrm{C}$ to $475^{\circ} \mathrm{C}$ and back to $25^{\circ} \mathrm{C}$. Although calcine deposits on the calciner wall are not a serious problem, vibrators mounted on the side of calciner wall are being tested to replace the top lid mounted vibrator.

Experiments with the wiped film evaporator were directed toward developing the transfer mechanism for transferring the evaporated slurry from the evaporator into the melter. Some plugging of this mechanism was experienced. Incorporation of the glass additive frit as a pulverized powder directly into the liquid feed to the evaporator has been successful. This technique provides chemical mixing and should lead to a more homogeneous lower melting glass.

Installation of the fluidized bed pilot plant has been completed, and the system is currently undergoing preliminary testing for startup. The unit will employ in-bed combustion and stainless steel off-gas filters.

A new waste composition, PW-7, has been added to the Waste Fixation Program. The waste is "clean," containing only $0.01 \mathrm{M} \mathrm{Na}$ and $0.1 \mathrm{M} \mathrm{Fe}$; however, it does contain inert gadolinium, a soluble poison added to the reprocessing plant dissolver.

Stored energy measurements have been completed on a series of neutron irradiated specimens and one ${ }^{244} \mathrm{Cm}$ doped specimen. A typical value of heat released for borosilicate glass is about $20 \mathrm{cal} / \mathrm{g}$. Initial release starts at temperatures below $150^{\circ} \mathrm{C}$. With borosilicate glass the rate increases as the temperature rises; it passes through a maximum and then drops to zero below $600^{\circ} \mathrm{C}$.

In radiolytic gas generation studies, a critical assessment is being made of the calcine material waste surface to determine the effects of gas adsorption, since this surface is expected to readsorb some of the radiolytically produced gasses. 
Sintering tests have been made with several types of calcine and glass frit mixtures, and their behavior during sintering has been monitored. Sintered pellets are formed at about $675^{\circ} \mathrm{C}$ and pressures as low as $12 \mathrm{psi}$. The sintered pellets appear to have good physical properties. They are quite dense, generally about $3.06 \mathrm{~g} / \mathrm{cc}$ where glass of about the same composition is about $3.24 \mathrm{~g} / \mathrm{cc}$. Leach test comparisons indicate about a factor of two higher leach rate for the pellets compared to 72-68 glass.

Carbon and SiC coated waste particle studies continued by incorporating samples of coated particles in an aluminum matrix. Although some corrosion of stainiess steel canisters may occur due to the aluminum, the encapsulation technique used for these tests looks attractive for a large scale process.

At Pennsylvania State University a feasibility study of the isolation of $\mathrm{PW}-4 \mathrm{~b}$ in inert $\mathrm{SiO}_{2}$ matrices by hot pressing is nearing completion. Development of modified calcine formulations consisting of PW-4b plus selected oxide additions to yield a refractory, low leachability ceramic calcine "supercalcine" has been initiated. 


\section{COMMERC IAL WASTE FIXATION}

DEVELOPMENTAL METALLIC MELTER - H. T. Blair

The purpose of this study is to develop a simple, dependable, durable, metallic melter for converting a mixture of glass forming frit and highlevel nuclear waste in the form of a calcine or a concentrated slurry to a durable glass. Such a melter must be adaptable both to continuous and batch modes of operation, operable at temperatures of 1150 to $1200^{\circ} \mathrm{C}$, and able to process melts having viscosities as high as 200 poise. To support an 8 metric ton per day fuel reprocessing plant, the melter must have a maximum capacity of approximately $200 \mathrm{lb}$ of melt per hour. This maximum capacity figure is based on a PW-7 ${ }^{(\mathrm{a})}$ type waste and a glass former to calcine ratio of $3: 1$.

One of the initial requirements for developing such a metallic melter is to identify a material for construction. Such a metal should have the following properties: 1) either high thermal conductivity or be a good suscepter for induction heating, 2) good resistance to attack by molten borosilicate glasses, 3) high mechanical strength at $\left.1200^{\circ} \mathrm{C}, 4\right)$ good thermal shock and spall resistance, and 5) resistance to radiation. Inconel ${ }^{\circledR} 690$ is the most promising alloy evaluated to date. (b) A melter fabricated from 1/2 inch Inconel 690 plate has been operated for 573 hours at temperatures in the range of $930^{\circ} \mathrm{C}$ to $1200^{\circ} \mathrm{C}$ for melting various batch compositions.

A failure was experienced in the drain tube of the melter after 445 hours of operation. This tube, with a wall thickness of $1 / 8$ in., was subjected to repeated thermal cycling because it is the freeze drain valve. Two axial cracks developed along seams where two plates had been joined to provide a bar thick enough to machine the tube from. A circumferential crack also developed just below the weld attaching the tube to the bottom of the melter.

a. See "Commercial Radioactive Waste Compositions Used in the Waste Fixation Program," this report.

(B) RTM International Nickel Company.

b. Quarterly Progress Report, BNWL-1741, p. 8, Apri1 1973. 
Metallographic examination of a cross section of the failed tube, Figure 1 , showed that it failed by the same mechanism as the agitator. (a) Corrosion penetrated $3 / 4$ of the thickness of the wa 11 , and 10 mils was completely dissolved from the inner wall during the 445 hours of use.

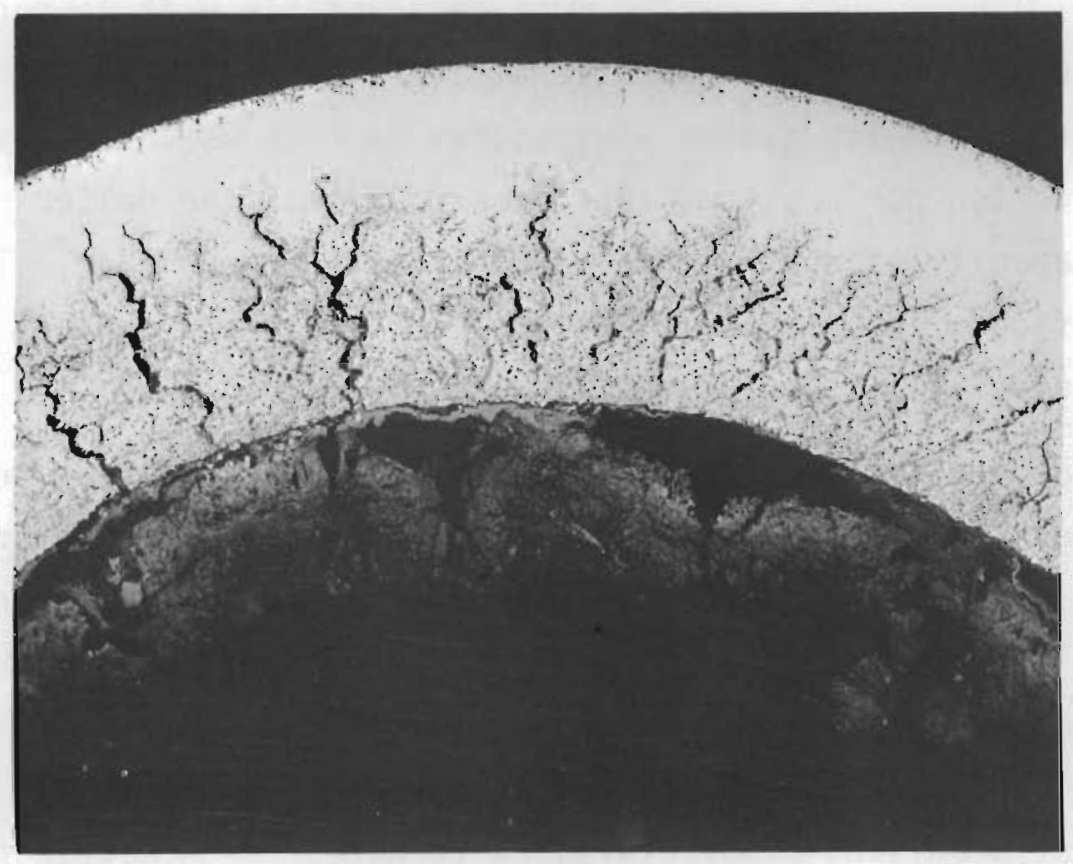

FIGURE 1. 12X Photomicrograph of Cross-Section of Melter Drain Tube Showing Extent of Corrosion after 445 Hours of Use

A section was cut from the bottom of the melter following failure of the drain tube. Examination of this section by metallographic techniques showed that the welded areas are more resistant to the type of corrosion being observed than is the metal plate. The photomicrographs show that the corrosion had penetrated as much as 0.125 inch below the surface of the

a. Quarterly Progress Report, BNWL-1841, p. 18, Ju1y 1974. 
metal plate. Approximately 0.36 in. of the original $1 / 2$ in. of alloy plate was unaffected after 445 hours at temperature while exposed to melt.

When the melter had experienced 539 hours at operating temperatures, wall thickness measurements were made using a Sperry Reflectroscope ultrasonic flaw detector having an estimated accuracy of \pm 0.01 in. General results indicated that the melter walls had eroded between 0.050 and $0.100 \mathrm{in}$. with pits noted to be as deep as $0.125 \mathrm{in}$. below the original surface. However, the weld joints were determined to be very close to their original thickness.

Because of the apparent resistance of the welds to corrosion, corrosion tests are being performed using samples of Inconel 601 and 690 with a weld overlay on one surface. The test specimens are rotated in a melt prepared from PW-7 calcine and 73-1 frit.

Several modifications have been made to the metallic melter during this reporting period. Following the failure of the original tube, the bottom of the melter was machined off and replaced with a new bottom and drain tube. The replacement parts are similar to the original in design, but the drain tube was fabricated from solid rod stock and the length of the melter was shortened by $1 / 4 \mathrm{in}$. as a result of the cutting and weld preparation.

A new agitator was installed to replace the turbine type previously used. The agitator is a paddle type made by putting a half twist lengthwise in a piece of $1 / 4$ in. $\times 17 / 8$ in. $x 6$ in. Incone 1690 plate. The drive shaft is welded to one side of the paddle. The agitator is positioned $1 / 2 \mathrm{in}$. off the bottom of the melter and is driven between 10 and $40 \mathrm{rpm}$ in a direction such that the twist forces melt downward. The paddle is intended more for thermal mixing than for melt homogenizing.

A thermocouple we 11 made from $1 / 8$ in. thick Incone 1690 tubing, bent so as to follow the walls of the melter to the bottom, has also been installed. This well will accommodate four $1 / 8 \mathrm{in}$. diameter type $K$ sheathed thermocouples. 
Five test runs were made with the metallic melter during this reporting period. Two runs were made with the melter directly coupled to the wiped film evaporator (WFE) to evaluate feeding a slurry to the melter. Two runs were made to determine the maximum melt viscosity that could be drained from the freeze valve and to evaluate the modifications to the melter. A fifth run was conducted to produce five glass castings for annealing studies and to evaluate the melter capacity.

The first run, made to demonstrate direct coupling of the melter to the WFE, was made without the aid of the agitator, and a large amount of second phase, determined to be $\mathrm{Zn}_{2} \mathrm{SiO}_{4}$, accumulated in the bottom of the melter and drain tube. During the second run with the WFE, the melter was operated with the paddle type agitator rotating at speeds of 42 to $120 \mathrm{rpm}$. A cold cap formed after the melt level rose above the paddle, which was rotating at $84 \mathrm{rpm}$ at the time. No second phase remained in the melter or drain tube following the run, al though samples of the melt taken during the draining contained large amounts of crystalline material. The details of the design of the coupling fixture, of the WFE operating conditions, and of the effects on the WFE are given elsewhere in this report.

The maximum melt viscosity runs were made because viscosity measurements made with the glass composition BPNL 74-55 showed that at the maximum operating temperature of the Incone 690 melter $\left(1150^{\circ} \mathrm{C}\right)$ the melt viscosity would be 150 poise or greater. To obtain melts having a viscosity in the range of 150 to 160 poise, the melter was charged with 73-1 frit, which was heated to $1000^{\circ} \mathrm{C}$ to $1050^{\circ} \mathrm{C}$ to accomplish complete melting and then cooled to $935^{\circ} \mathrm{C}$ during one run and $920^{\circ} \mathrm{C}$ during the other. The freeze valve operated effectively for initiating and terminating draining of the viscous melts. The melts drained at rates of between $27 \mathrm{lb} / \mathrm{hr}$ and $46 \mathrm{lb} / \mathrm{hr}$. The rates decreased as the head in the melter decreased. Values for the viscosity of the melts calculated using the Hagen-Poiseville Law ranged between 153 to 162 poise. 
The new agitator rotating at only 40 RPM performed satisfactorily for achieving a uniform temperature throughout the melt. This slower rotational speed will reduce the corrosion rate of the melter parts.

No problems were experienced with stalagmite formation when casting a monolith with these low temperature, high viscosity melts. However, glass stringing from the freeze drain valve was a problem.

The fifth run, designated MM-3, was made to prepare five $35 \mathrm{lb}$ mono1iths for annealing studies. Crushed 72-68 (PW-4b-2:[3.0]73-1) type glass was fed by a vibrating trough feeder to the melter through one of the side ports in the melter cap. The offgas was extracted through another of the ports at flow rates of 1 to 2 SCFM through a 1/2-in. ID tube. The twisted paddle-type agitator was driven at $10 \mathrm{rpm}$ during the entire run. The first $351 \mathrm{~b}$ of cullet was charged to the melter while it was at room temperature and was heated with the melter to $1150^{\circ} \mathrm{C}$. Melter capacity and power requirements recorded during melting of the five batches are presented in Table 1.

TABLE 1. Me1ter Capacity and Power Requirements

\begin{tabular}{|c|c|c|c|c|}
\hline Batch No. & $\begin{array}{l}\text { Average Feed } \\
\text { Rate, } 1 \mathrm{~b} / \mathrm{hr}\end{array}$ & $\begin{array}{r}\text { Time to } \\
1150^{\circ} \mathrm{C}, \mathrm{hr} \\
\end{array}$ & $\begin{array}{r}\text { Melting } \\
\text { Rate, } 1 \mathrm{~b} / \mathrm{hr} \\
\end{array}$ & $\begin{array}{c}\text { Power Required } \\
\mathrm{kW} \mathrm{hr/lb}\end{array}$ \\
\hline 1 & $N A^{(a)}$ & 16.8 & $N A^{(a)}$ & 2.5 \\
\hline 2 & 25.9 & 1.75 & 20.0 & 0.51 \\
\hline 3 & 39.6 & 1.35 & 25.9 & 0.40 \\
\hline 4 & 51.2 & 1.42 & 24.6 & $N A(a)$ \\
\hline 5 & 26.6 & 1.85 & 18.9 & 0.54 \\
\hline
\end{tabular}

a. Not applicable 
The temperature in the melter dropped to $900^{\circ} \mathrm{C}$ while the cullet was being fed and required between 24 and 44 minutes to return to $1150^{\circ} \mathrm{C}$ after feeding was complete. An attempt was made with batch 5 to vary the feed rate so that the melt temperature never dropped below $1000^{\circ} \mathrm{C}$. The result was less efficient than feeding at approximately $40 \mathrm{lb} / \mathrm{hr}$ and letting the temperature at the surface of the melt drop to $900^{\circ} \mathrm{C}$. These results indicate the capacity of the developmental metalic melter is near 620 lb of melt per day, which is equivalent to $1.1 \mathrm{MTU} /$ day.

Following run MM-3, the melter was disassembled for inspection. A layer of crystalline material had accumulated on the bottom of the melter and the off-gas line was partially filled with deposits of fine dust.

JOULE HEATED CERAMIC MELTER - C. C. Chapman

Melter Description

A ceramic melter has been designed and constructed to melt the low temperature glass composition (72-68). Figure 2 gives a cross-sectional view of the melting cavity and the overflow drain. The interior dimensions of the melting cavity are 9 in. wide, 21 in. long and $12 \mathrm{in.} \mathrm{deep.} \mathrm{The} \mathrm{nominal}$ depth of the molten glass during production melting is 6 inches. Located at both ends of the melting cavity are the plate electrodes, 9 in. wide and 6 in. high.

The melter can be drained by either of two separate drainage systems: a bottom drain freeze valve allows the melter to be drained completely, and the other drain is an overflow drain. The overflow drain, adjacent to the melting cavity, is connected to the melting cavity by a tunnel at the floor. During production melting, the plug is periodically raised by the air cylinder for batch dumping into a receiving canister.

Operational testing of this melter has been limited to short runs due to auxiliary equipment failures in the melter's power supply system. The melter was successfully started up on six separate occasions using the 


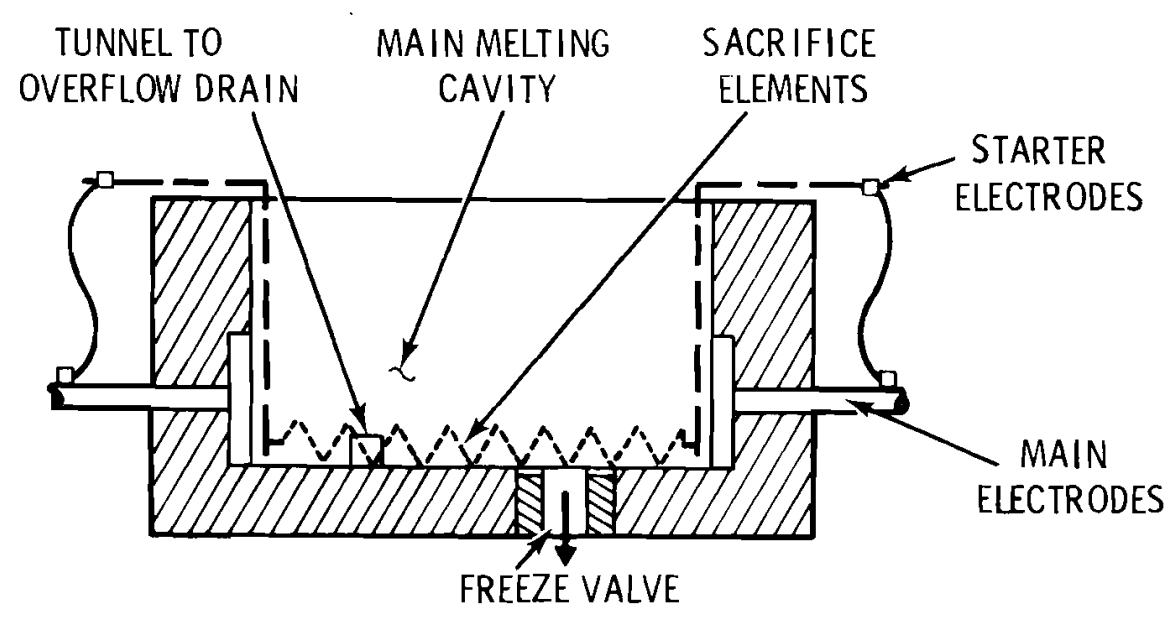

SECTION VIEW OF MAIN MELTING CAVITY

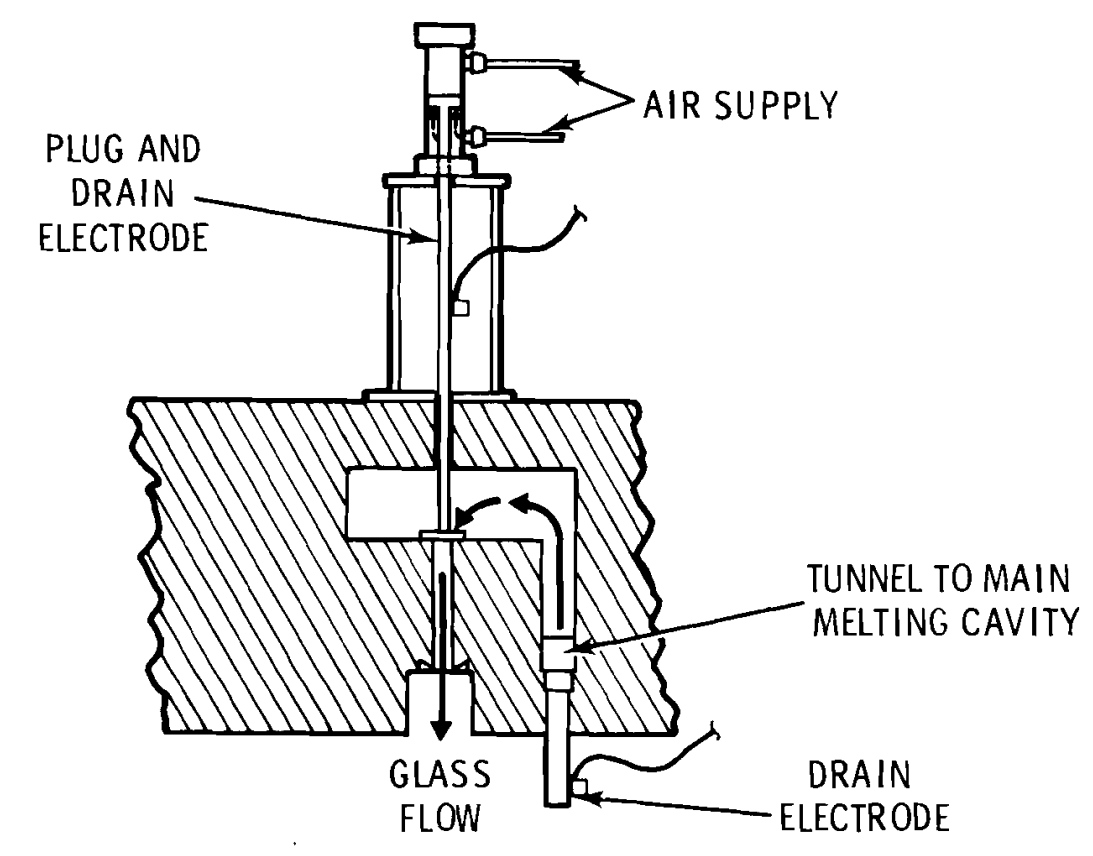

SECTION OF OVERFLOW DRAIN

FIGURE 2. Ceramic Melter, Cross-Sectional Views 
startup technique described below. Defective equipment resulted in frozen tanks. The successful restarts following these troublesome conditions demonstrate the reliability of this startup technique.

Startup Technique

The sacrifice element startup technique employs resistance wires and starter electrodes as shown by the dashed lines in Figure 2. The resistance wire and starter electrodes are made from materials which rapidly corrode in molten glass at elevated temperatures. The resistance wire and starter electrodes are lowered into the cavity and attached in parallel with the main electrodes. After the resistance wire is covered with glass frit, power is applied to attain a desired increase in temperature. As the temperature in the glass frit increases to the melting range, a conductive path through the glass between the starter electrodes is established. As the glass temperature continues to increase, the entire cavity becomes molten and continuity between the ma in electrodes through the glass is accomplished. When the glass temperature approaches operating temperatures, the resistance wire and starter electrodes are rapidly dissolved into the glass and the melter is ready for production melting.

Using the above technique, the melter has been brought to the operating temperature of $1200^{\circ} \mathrm{C}$ as rapidly as $300^{\circ} \mathrm{C} / \mathrm{hr}$ and as slowly as $6^{\circ} \mathrm{C} / \mathrm{hr}$. The demonstrated reliability of this technique and its adaptability to remote operation has resolved one of the major concerns of the ceramic melter for use in a hot cell operation.

\section{IN-CAN MELTING - R. B. Dakan}

The purpose of this study is to further develop a method of directly melting calcine in the waste storage canister. In-can melting (ICM) has been successfully demonstrated on a laboratory scale (800 g samples) at 950 and $1000^{\circ} \mathrm{C}$. Of the four ICM tests (two at 950 and two at 1000) only the two runs at $950^{\circ} \mathrm{C}$ have been leach tested. The composition was approximately $25 w t \%$ PW- $4 b$ calcine and $75 w t \%$ 73-1 frit. These tests showed a 
$0.89 \%$ and $5.7 \%$ weight loss by the Sohxlet accelerated leach test after 24 hours for ICM-1 and ICM-2, respectively. The high value for ICM-2 is probably due to devitrification, incomplete calcine-frit reaction, and possible loss of tiny particles of the sample. ICM-3 and -4 should be of as high or higher quality than ICM-1. ICM-4 tested the viability of feeding a $70 \%$ solids slurry. In each test run, a noticeable amount of cerium collected at the bottom of each crucible, indicating some phase separation or incomplete dissolution.

A feed and off-gas system has been designed that will permit large scale tests ( $5 \mathrm{ft}$ cans, 8-in. diameter). The most important parameters to be measured are the maximum melting rate and the leach rate of the product. If the reprocessors' calcine waste canisters are reused as glass canisters, the presence of cooling fins inside should increase the melting capacity.

Corrosion studies are being performed to evaluate possible canister materials. For the laboratory scale tests performed to date, $304 \mathrm{~L}$ stainless steel crucibles have been used with very little visible corrosion. No corrosion tests have been made with $\mathrm{PW}-7$ calcine.

\section{DIRECT MELTING IN REFRACTORY CONTAINERS - J. L. Bates}

The purpose of this study was to develop a technique and material system whereby waste glass could be melted directly with the heat generated by induction coupling with the container. Such a container might also be used as the final storage canister. The container must have good compatibility with the molten glass and should exhibit a good thermal conductivity, electrical conductivity, mechanical strength, thermal shock resistance and radiation stability.

SiC coated graphite has been evaluated for this purpose. Although it meets nearly all necessary requirements, the results show that the SiC reacts with waste glass. 
Crucibles, 3 in. OD, $21 / 2$ in. ID, 3 in. deep, and $31 / 2$ in. 1ong, were coated with SiC. The coating thickness varied from 0.008 to $0.018 \mathrm{~cm}$ thick and was applied by chemical vapor deposition (CVD) techniques. These crucibles were filled with three waste glass compositions: 73-109, 72-68, and the AEC basalt-salt cake waste. Heating was in air, using a $400 \mathrm{KHz}$ RF generator for periods up to 3 hours. Temperatures on the crucible outside surfaces were approximately 1300 to $1350^{\circ} \mathrm{C}$. The inside temperatures were estimated to be near $1450^{\circ} \mathrm{C}$.

Al though the reaction varied for each waste, all resulted in the deterioration of the SiC coating. All exhibited extensive gas formation next to the crucible inner surface. This has been attributed to: a) the reaction of glass with $\mathrm{SiC}$ to form $\mathrm{CO}_{2}$ at the surface, b) the deterioration of the $\mathrm{SiC}$ resulting in the oxidation of the graphite forming $\mathrm{CO}$ and $\mathrm{CO}_{2}$, and/or c) loss of volatile products such as zinc from the waste glass.

Metallographic examination of waste glass 73-109 and the SiC coated crucible showed these unsatisfactory results:

1. Extensive reaction resulting in partial or total removal of the SiC coating adjacent to the molten waste glass. Reaction was greatest near the top of the liquid nearest the air atmosphere.

2. The SiC coating on the outside surface diffused through the porous graphite toward the inner surface of the crucible. Penetration was approximately one fourth the wall thickness. This effect was observed only across from the location of the waste glass.

3. The glass contained large gas bubbles, especially near the glassSic interface.

4. The waste glass showed extensive devitrification with the formation of large ( $20.005 \mathrm{~cm}$ diameter) crysta $1 \mathrm{~s}$ uniformly distributed throughout the glass. Past experience would indicate these to be $\mathrm{ZrO}_{2}-\mathrm{SiO}_{2}$. Extensive vaporization loss of zinc would enhance this devitrification. 
The resistance of $\mathrm{SiC}$ in air is dependent upon the formation of a protective $\mathrm{SiO}_{2}$ coating. However, the $\mathrm{SiO}_{2}$ is easily dissolved in the waste glass, resulting in the oxidation of the $\mathrm{SiC}$ to $\mathrm{SiO}_{2}$ and further dissolution.

Alternative coatings for graphite are being considered which may be resistant to the molten waste glass.

DEVELOPMENTAL SPRAY CALCINER - H. T. Blair

The reference or standard batches of $P W-4 b$ and $P W-6$ type calcines (a) were characterized, and the physical properties are presented in Tables 2 and 3 .

TABLE 2. Physical Properties of Reference Calcines

\begin{tabular}{lllll} 
Characteristic & & PW-4b & PW-6 \\
\cline { 1 - 1 } Aerated Bulk Density, g/cc & & 0.85 & 0.41 \\
Working Bulk Density, g/cc & & 0.97 & 0.48 \\
Packed Bulk Density, g/cc & & 1.24 & 0.61 \\
Compressibility, $\%$ & & 31.8 & 32.8 \\
Angle of Repose, degrees & 42 & 39
\end{tabular}

TABLE 3. Results of Sieve Analys is of Reference Calcines

\begin{tabular}{ccccr}
\multicolumn{2}{c}{ U.S. Standard Sieve } & & \multicolumn{2}{c}{ Cumulative Weight \% Retained } \\
\cline { 1 - 2 } Mesh No. & Size & & PW-4b & PW-6 \\
\cline { 5 - 5 }+18 & $>1.00 \mathrm{~mm}$ & & 0.50 & 0.25 \\
+35 & $>500 \mu$ & & 0.94 & 0.36 \\
+45 & $>354 \mu$ & & 1.43 & 0.44 \\
+60 & $>250 \mu$ & 1.53 & 1.47 \\
+80 & $>177 \mu$ & 1.65 & 2.55 \\
+170 & $>88 \mu$ & 1.79 & 3.75 \\
+325 & $>44 \mu$ & 1.84 & 11.57 \\
-325 & $<44 \mu$ & 100.00 & 100.00
\end{tabular}

The $\mathrm{pH}^{\prime} \mathrm{s}$ of the reference calcines dampened with deionized water were determined to be 4.5 for the $\mathrm{PW}-4 \mathrm{~b}$ and 5.0 for the $\mathrm{PW}-6$.

a. Quarter1y Progress Report, BNWL-1841, p. 13, Ju1y 1974. 
The angle of repose, compressibility, bulk density, and small particle size of these calcines indicate flow characteristics that may make bin storage and conveying difficult. The calcine can be agglomerated to reduce dusting and make it more flowable. Several agglomerating techniques are available: disc and drum pelletizing, briquetting, extrusion, and pressing. The agglomeration process can be combined with the frit addition to the calcine so that the agglomerate will be a homogeneous, free-flowing blend of waste calcine and frit that will not separate during conveying. A homogeneous blend of the nuclear waste calcine and the glass formers is considered desirable because discussions with the manufacturers of glass melting equipment have revealed that a homogeneous melt is more successfully achieved by mixing the batch than by mixing the melt.

Three $\mathrm{B}_{4} \mathrm{C}$ inserts and three $96 \%$ alumina air caps for the spray nozzle used in the developmental spray calciner were obtained during the last reporting period. (a) Two of the $\mathrm{B}_{4} \mathrm{C}$ inserts were diamond ground to the desired dimensions and interference fit by differential thermal expansion methods into air caps machined from 304 stainless steel. One air cap with the $\mathrm{B}_{4} \mathrm{C}$ insert and one made from $96 \%$ alumina were rapidly cycled three times from $25^{\circ} \mathrm{C}$ to $475^{\circ} \mathrm{C}$ and back to $25^{\circ} \mathrm{C}$ to simulate the therma 1 shock conditions expected in the spray calciner. Both caps were unaffected by the thermal cycling.

Two modified Cleveland 1300 AC Vibra-Might vibrators were received and installed on the spray calciner. (b) These vibrators are mounted on springs in housings and fitted with extension shafts which permitted mounting them on the exterior shell of the spray calciner furnace. The extension shafts pass through tunnels in a 2-inch spacer of insulation placed between the upper and lower zones of the furnace and act on impact pads welded to the outside wall of the spray calciner barrel. The vibrators are located approximately $180^{\circ}$ apart on the circumference of the barrel and at the center of its length.

a. Quarterly Progress Report, BNWL-1841, p. 16, July 1974.

b. Quarterly Progress Report, BNWL-1841, p. 17, July 1974. 
While the spray calciner barrel was out of the furnace for installation of the impact pads, wall thickness measurements were made to compare with those taken before the barrel was put into service. The results show that after 552 hours of feed calcining with six associated heat-up and cooldown cycles, there has been no detectable corrosion of the 3/8-inch 310-SS wall. The precision of the measuring instrument is 0.002 inch.

WIPED FILM EVAPORATOR - R. D. DierkS

Two experiments were conducted with the wiped film evaporator facility to evaluate the feasibility of directly coupling a low temperature $\left(120^{\circ} \mathrm{C}\right)$ evaporator unit to a high temperature $\left(1100^{\circ} \mathrm{C}\right)$ melter unit. For these experiments the $5-\mathrm{ft}^{2}$ horizontal Artisan-Kantro wiped film evaporator was positioned directly above a metallic-type melter, heated with a radiant resistance element electric furnace. Feed to the evaporator was a simulated high-level waste containing a 3:1 ratio of pulverized (<325 mesh) glass former frit to waste metal oxide, with nitric acid added to maintain the resulting slurry as a creamy suspension.

In both experiments the operation of the evaporator with the fritbearing waste slurry was uneventful, with the concentrate dropping smoothly into the melter without spattering or foaming. The major problem encountered in both experiments was with the transfer section in which the concentrate is conveyed from the evaporator to the melter. In both experiments the concentrate prematurely calcined in the transfer section and obstructed the flow of concentrate from the evaporator. Additional experiments are planned to optimize the design of the transfer section and the operation of the evaporator to match the heat transfer capabilities of the melter. 
FLUIDIZED BED CALCINER - W. J. Bjorklund

Installation of the fluidized bed calciner system has been completed in EDL-102 of the 324 Building. A11 instrumentation and control systems have been installed. Equipment shakedown and startup tests are presently under way. Scheduled startup is for early in the coming quarter. A simplified flow diagram is shown in Figure 3, and a photograph of the calciner vessel and filter chamber is shown in Figure 4. Several remotable features were incorporated into the equipment design, including feed and fuel nozzles and $\mathrm{a}$ bed inspection port.

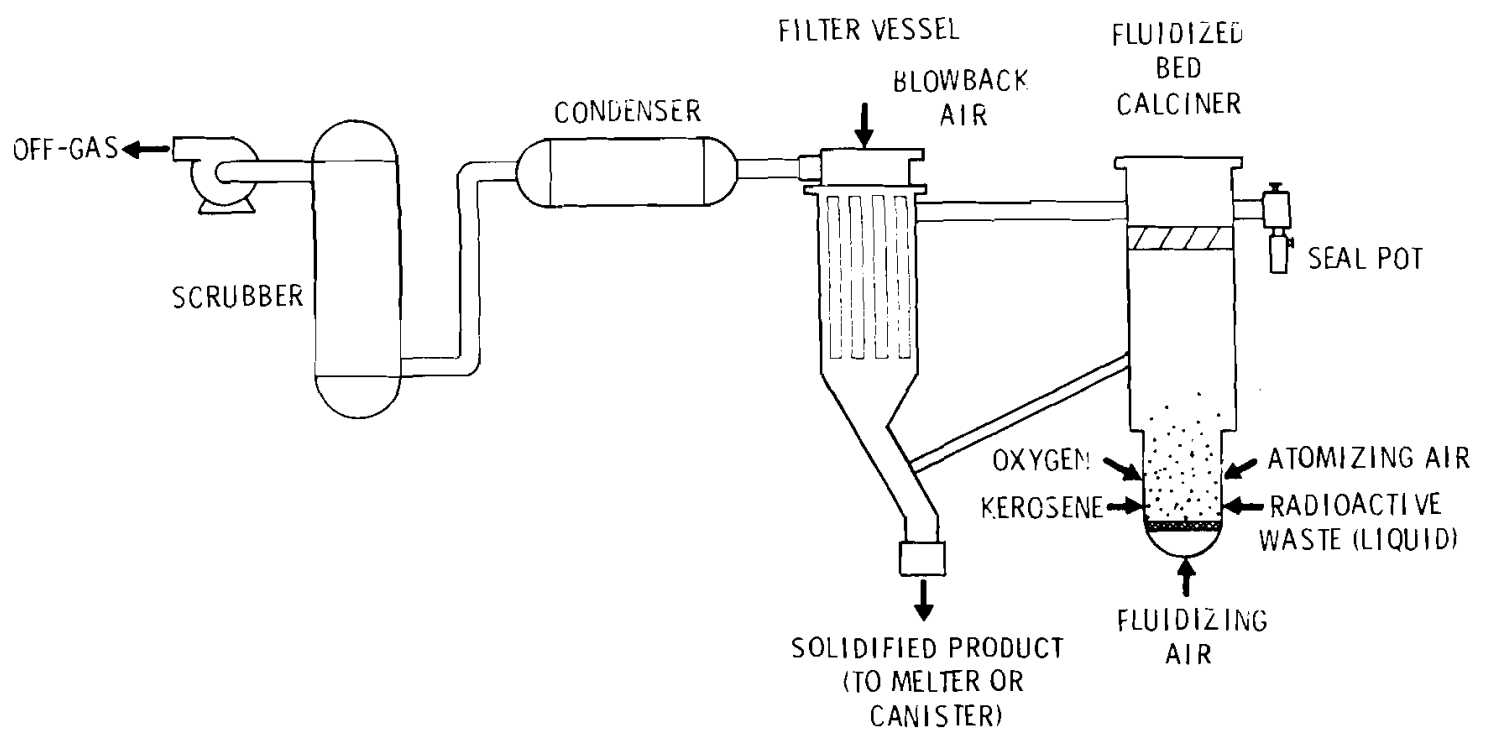

FIGURE 3. Process Flow for the Fluidized Bed Calciner System 


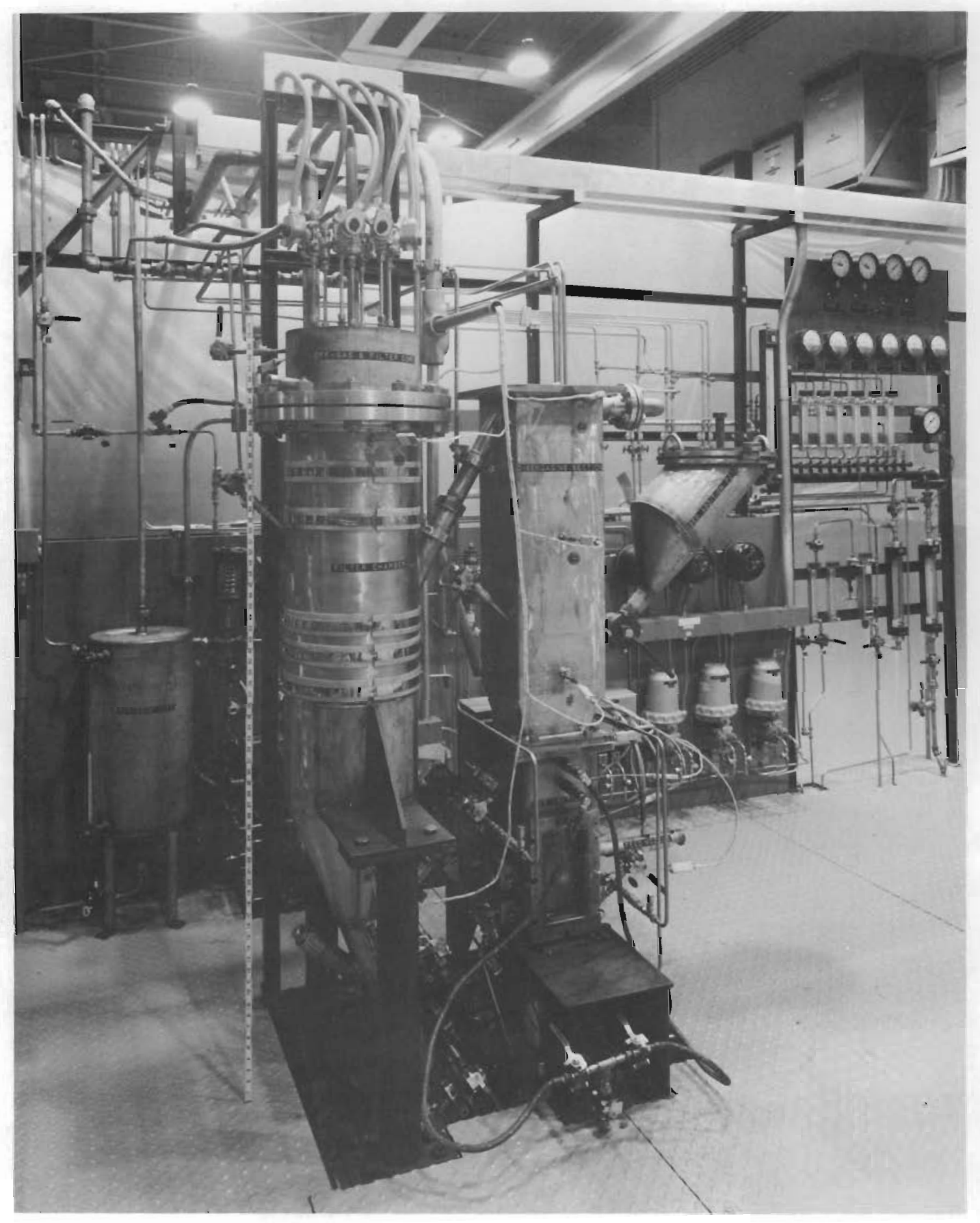

FIGURE 4. Calciner Vessel and Filter Chamber 


\section{PRODUCT CHARACTERIZATION}

COMMERCIAL RADIOACTIVE WASTE COMPOSITION USED IN THE WASTE

FIXATION PROGRAM - J. E. Mende 1

A new waste composition, PW-7, which reflects the latest trends in U. S. commercial fuel reprocessing, has been added to the Waste Fixation Program. The waste is "clean," containing only $0.01 \mathrm{M} \mathrm{Na}$ and $0.1 \mathrm{M} F$ However, it does contain inert gadolinium, present because it is added to the dissolvers as a soluble poison. The added gadolinium increases the total rare earth content of the waste by a factor of 1.74. The uranium and plutonium waste loss assumed for $\mathrm{PW}-7$ is $1 \%$, higher than in previous reference waste solutions. This high waste loss is not projected for normal operation but would be acceptable and therefore is being included in this reference waste as a potential possibility. The phosphate concentration is four times that present in previous wastes, making $\mathrm{P}_{2} \mathrm{O}_{5}$ a significant constituent of the calcined waste at over 4 wt\%.

The reference waste solutions used in the Waste Fixation Program are selected to keep current with projected commercial reprocessing plans. Thus the PW-7 reference waste composition in Table 4 is representative of the latest projected high-level waste composition for the Barnwell plant. Similarly, work on the reference waste compositions PW-4c and PW-6 (see Table 7 in BNWL-1841) has been curtailed because waste with those compositions may not be created. $P W-4 c$ was representative of the Midwest Fuel Recovery Plant, which is no longer planned to be operated. PW- 6 was representative of an earlier Barnwell plant flowsheet, now supplanted by the flowsheet which yields PW-7. 


\begin{tabular}{|c|c|c|c|c|c|c|c|c|c|c|c|c|c|c|c|c|c|c|c|c|c|c|c|}
\hline & \multicolumn{23}{|c|}{ FISSION PRODUCTS } \\
\hline & \multicolumn{22}{|c|}{ MOLARITY IN SOLUTION CONTAINING WASTE FROM 1 MTU IN 378.5 LITERS } & \multirow{3}{*}{$\begin{array}{c}\text { KILOGRAMS } \\
\text { OXIDE PER } \\
\text { MTU }\end{array}$} \\
\hline & $\mathrm{Rb}$ & $\mathrm{Sr}$ & $Y$ & $\mathrm{Zr}$ & Mo & $\mathrm{TC}$ & $\mathrm{Ru}$ & $\mathrm{Rh}$ & $\mathrm{Pd}$ & $\mathrm{Ag}$ & $\mathrm{Cd}$ & $\mathrm{Te}$ & Cs & $\mathrm{Ba}$ & La & $\mathrm{Ce}$ & $\mathrm{Pr}$ & Nd & $\mathrm{Pm}$ & $\mathrm{Sm}$ & Eu & $G d$ & \\
\hline & $\mathrm{Rb}_{2} \mathrm{O}$ & sro & $\mathrm{Y}_{2} \mathrm{O}_{3}$ & $\mathrm{ZrO}_{2}$ & $\mathrm{MOO}_{3}$ & $\mathrm{TC}_{2} \mathrm{O}_{7}$ & $\mathrm{RuO}_{2}$ & $\mathrm{Rh}_{2} \mathrm{O}_{3}$ & $\mathrm{PdO}$ & $\mathrm{Ag}_{2} \mathrm{O}$ & $\mathrm{CdO}$ & $\mathrm{TeO}_{2}$ & $\mathrm{Cs}_{2} \mathrm{O}$ & $\mathrm{BaO}$ & $\mathrm{La}_{2} \mathrm{O}_{3}$ & $\mathrm{CeO} 2$ & $\operatorname{Pr}_{6} \mathrm{O}_{11}$ & $\mathrm{Nd}_{2} \mathrm{O}_{3}$ & $\mathrm{Pm}_{2} \mathrm{O}_{3}$ & $\mathrm{Sm}_{2} \mathrm{O}_{3}$ & $\mathrm{Eu}_{2} \mathrm{O}_{3}$ & $\mathrm{Gd}_{2} \mathrm{O}_{3}$ & \\
\hline AS-DEFINED PW $-7^{(\mathrm{C})}$ & 0.010 & 0.027 & 0.014 & 0.106 & 0.095 & 0.022 & 0.059 & 0.010 & 0.032 & 0.002 & 0.002 & 0.012 & 0.054 & 0.027 & 0.024 & 0.051 & 0.023 & 0.071 & 0.0019 & 0.014 & 0.003 & 0.002 & 35.9 \\
\hline PW-7-1 & 0.010 & 0.027 & $\begin{array}{c}0.0006 \\
(\mathrm{RE})(\mathrm{d}) \\
\end{array}$ & 0.106 & 0.095 & $\begin{array}{l}0.022 \\
\text { (Mo) }\end{array}$ & \begin{tabular}{|l|}
0.059 \\
$(\mathrm{Fe})$
\end{tabular} & $\begin{array}{l}0.010 \\
(\mathrm{Co})\end{array}$ & $\begin{array}{l}0.032 \\
\text { (Ni) }\end{array}$ & 0.002 & 0.002 & 0.012 & 0.054 & 0.027 & \begin{tabular}{|l|}
0.052 \\
(RE)
\end{tabular} & $\begin{array}{l}0.098 \\
\text { (RE) }\end{array}$ & \begin{tabular}{l|}
0.010 \\
(RE)
\end{tabular} & $\begin{array}{l}0.036 \\
\text { (RE) }\end{array}$ & $\overline{---}$ & \begin{tabular}{|l|}
0.006 \\
(RE)
\end{tabular} & $\begin{array}{l}0.002 \\
\text { (RE) }\end{array}$ & $\begin{array}{l}0.004 \\
\text { (RE) }\end{array}$ & 34.4 \\
\hline
\end{tabular}

\begin{tabular}{|c|c|c|c|c|c|c|c|c|c|c|c|c|c|c|}
\hline & \multicolumn{6}{|c|}{ ACTINIDES } & \multicolumn{8}{|c|}{ INERTS } \\
\hline & \multicolumn{5}{|c|}{ MOLARITY, @ 378.5 LITER/MTU } & \multirow{3}{*}{$\begin{array}{c}\text { KILOGRAMS } \\
\text { OXIDE PER } \\
\text { MTU }\end{array}$} & \multicolumn{7}{|c|}{ MOLARITY, @ 378.5 LITERS/MTU } & \multirow{3}{*}{$\begin{array}{c}\text { KILOGRAMS } \\
\text { OXIDE PER } \\
\text { MTU }\end{array}$} \\
\hline & $\mathrm{U}$ & $\mathrm{Np}$ & $\mathrm{Pu}$ & $\mathrm{Am}$ & $\mathrm{Cm}$ & & $\mathrm{Na}$ & $\mathrm{Fe}$ & $\mathrm{Al}$ & $\mathrm{Cr}$ & $\mathrm{Ni}$ & $\mathrm{PO}_{4}$ & Gd & \\
\hline & $\mathrm{U}_{3} \mathrm{O}_{8}$ & $\mathrm{NpO}_{2}$ & $\mathrm{PuO}_{2}$ & $\mathrm{Am}_{2} \mathrm{O}_{3}$ & $\mathrm{CmO}_{2}$ & & $\mathrm{Na}_{2} \mathrm{O}$ & $\mathrm{Fe}_{2} \mathrm{O}_{3}$ & $\mathrm{Al}_{2} \mathrm{O}_{3}$ & $\mathrm{Cr}_{2} \mathrm{O}_{3}$ & $\mathrm{NiO}$ & $\mathrm{P}_{2} \mathrm{O}_{5}$ & $\mathrm{Gd}_{2} \mathrm{O}_{3}$ & \\
\hline AS-DEFINED PW- $7^{(C)}$ & 0.110 & 0.0085 & 0.001 & 0.0018 & 0.0004 & 12.9 & 0.010 & 0.10 & -- & 0.012 & 0.005 & 0.10 & 0.151 & 16.7 \\
\hline PW-7-1 & 0.110 & $\begin{array}{l}0.0085 \\
\text { (U) }\end{array}$ & $\begin{array}{c}0.001 \\
\text { (U) }\end{array}$ & $\begin{array}{l}0.0018 \\
\text { (RE) }\end{array}$ & $\begin{array}{c}0.0004 \\
\text { (RE) }\end{array}$ & 12.8 & 0.010 & 0.10 & --- & 0.012 & 0.005 & 0.10 & 0.151 & 16.7 \\
\hline
\end{tabular}

a. This is a supplement to Table 7 in BNWL-1841 the April June, 1974 quarterly report.

b. Where used, chemical substitutes are shown in parentheses below corresponding concentration.

c. Fission products represent LWR fuel with burnup $=33,000 \mathrm{MWD} / \mathrm{MT}$, power level $=30 \mathrm{MW} / \mathrm{MT}$, 150 days out of reactor. U ranium and plutonium concentrations represent $1.0 \%$ loss to waste during processing.

d. A commercial rare earth mixture is used, nominally containing (wt\%), $0.2 \mathrm{Y}_{2} \mathrm{O}_{3}, 24.0 \mathrm{La}_{2} \mathrm{O}_{3}, 48.0 \mathrm{CeO} 2,5.0 \mathrm{Pr} 6 \mathrm{O}_{11}, 17.0 \mathrm{Nd}_{2} \mathrm{O}_{3}, 3.0 \mathrm{Sm}_{2} \mathrm{O}_{3}, 0.8 \mathrm{Eu} 2 \mathrm{O}_{3}$ and $2.0 \mathrm{Gd} 2 \mathrm{O}_{3}$. 
STORED ENERGY MEASUREMENTS - F. P. Roberts, J. E. Mende 1 and J. E. Gose

Heavy particle interactions with the atoms of a solid can cause dislocations or other effects within the solid which result in metastable energy states. When the solid is subsequently heated, energy is released equal to the difference between ground state and the metastable state.

This study is designed to determine the magnitude of the stored energy and the characteristics of its release in stored solid radioactive wastes.

Calculations have shown that the principal source of radiation damage giving rise to stored energy is the interactions with alpha particles and the associated heavy particle recoils from the decay of the actinide elements in the waste. Neutrons and fission fragments will also contribute an additional amount of damage, but beta and gamma interaction will have only minor effects.

The experiments are being carried out using synthetic waste specimens which have ${ }^{244} \mathrm{Cm}$ incorporated in them and with specimens irradiated by neutrons in the Oak Ridge Reactor at Oak Ridge National Laboratory. The release of stored energy is measured using a differential scanning calorimeter (DSC) at PNL. Some measurements are also being carried out at ORNL by means of a drop calorimeter. The DSC has the advantage of permitting observation of the energy release as a function of the specimen temperature but is 1 imited to operating temperature ranges below $600^{\circ} \mathrm{C}$. The drop calorimeter has the advantage of much higher operating temperatures, but can make measurements only at a single temperature.

Stored Energy Release

Measurements have been completed on a series of neutron irradiated specimens and one ${ }^{244} \mathrm{Cm}$ doped specimen. The results are summarized in Table 5. Comparison between the results of the DSC and the drop calorimeter indicates significant differences. These are explained by the fact that the release of energy is not always complete at $600^{\circ} \mathrm{C}$ (the upper 1 imit of the DSC). DSC scans of specimens SEN-1, SEN-2, SEN-3 and SEN-9 all show that heat is still being evolved at $600^{\circ} \mathrm{C}$. 


\section{TABLE 5. Summary of Stored Energy Measurements}

\begin{tabular}{|c|c|c|c|c|}
\hline Sample & & & Hea & Release, $\mathrm{Cal} / \mathrm{g}$ \\
\hline Number & Composition & Irradiation & DSC $(\mathrm{C})$ & Drop Ca lorimeter $(d)$ \\
\hline SEN-1 & $\begin{array}{l}\mathrm{A} 12^{0} \text { spheres coated } \\
\text { with Type } 2 \mathrm{PW}-4 \mathrm{~b} \\
\text { calcine }(34.7 \text { wt } \%)\end{array}$ & $\begin{array}{r}2.3 \times 10^{20(a)} \\
\text { Neutrons } / \mathrm{Cm}^{2}\end{array}$ & 4.4 & $\begin{aligned} 18, & 13(743) \\
7 & (512)\end{aligned}$ \\
\hline SEN-2 & $\begin{array}{l}\text { Type } 1 \text { PW-4b Calcine } \\
(100 \%)\end{array}$ & $"$ & 6.2 & $18,24(897)$ \\
\hline SEN-3 & $\mathrm{Al}_{2} \mathrm{O}_{3}$ spheres $100 \%$ & $"$ & 5.6 & $\begin{array}{c}12,13(978) \\
24(736)\end{array}$ \\
\hline SEN-4 & $\begin{array}{l}\text { Borosilicate glass - } \\
70 \text { wt } \% \text { Frit } 111-15 \text {, } \\
30 w t \% \text { PW- } 4 m \text { waste } \\
\text { oxide }\end{array}$ & $"$ & 19.2 & $\begin{array}{c}17,19(510) \\
11(333)\end{array}$ \\
\hline SEN-5 & $\begin{array}{l}\text { Borosilicate glass - } \\
75 \text { wt } \% \text { Frit } 73-149, \\
25 w t \% \text { PW- } 4 \text { b waste } \\
\text { oxide }\end{array}$ & " & 19.7 & $\begin{array}{c}23,25(510) \\
11(334)\end{array}$ \\
\hline SEN -7 & $\begin{array}{l}\text { Silica glass - } 50 \text { wt } \% \\
\mathrm{SiO}_{2}, 50 \mathrm{wt} \% \mathrm{PW}-4 \mathrm{~m} \\
\text { waste oxide }\end{array}$ & $"$ & 28.3 & $27,32(838)$ \\
\hline SEN-9 & $\begin{array}{l}\text { Silica glass - } 100 \% \\
\text { crushed quartz }\end{array}$ & $"$ & 7.9 & $32,37,52(976)$ \\
\hline$A-3$ & $\begin{array}{l}\text { Borosilicate glass - } \\
70 \text { wt } \% \text { Frit } 73-1, \\
30 \text { wt } \% \text { PW- } 4 \text { b waste } \\
\text { oxide, } 0.69 \text { wt } \% \\
244 \mathrm{Cm}\end{array}$ & $\begin{array}{l}5.0 \times 10^{17(b)} \\
\text { Alphas/gram of } \\
\text { waste }\end{array}$ & 16.1 & -- \\
\hline
\end{tabular}

a. This neutron irradiation is estimated to be equivalent to the alpha disintegrations resulting in waste from a $L W R \mathrm{UO}_{2}$ equilibrium fuel cycle over a period of seven years after processing ${ }^{2}$ (BNWL-1741, pp. 31-33, and ORNL-TM-3781).

b. This is estimated to be equivalent to the alpha disintegrations resulting in wastes from a LWR $U_{2}$ equilibrium fuel cycle over a period of 40 years after processing.

c. Al1 measurements were over a range of 50 to $600^{\circ} \mathrm{C}$.

d. The numbers in parenthesis following the heat value represent the temperature at which the drop calorimeter measurement was made. 


\section{Rate of Energy Release}

The DSC permits the observation of energy release as a function of the specimen temperature. The measurement is made by performing two or more scans on the same sample of a specimen. The first scan measures the heat release plus any other thermal effects. The second scan represents a baseline which should include all thermal effects except the stored energy release. The area between the two scans is proportional to the amount of energy released and from a known calorimeter sensitivity at each temperature (obtained by a prior calibration) the absolute heat release can be calculated. Figure 5 is typical of the calorimeter output. The rates of energy release as a function of sample temperatures for some of the specimens are shown in Figures 6 through 10.

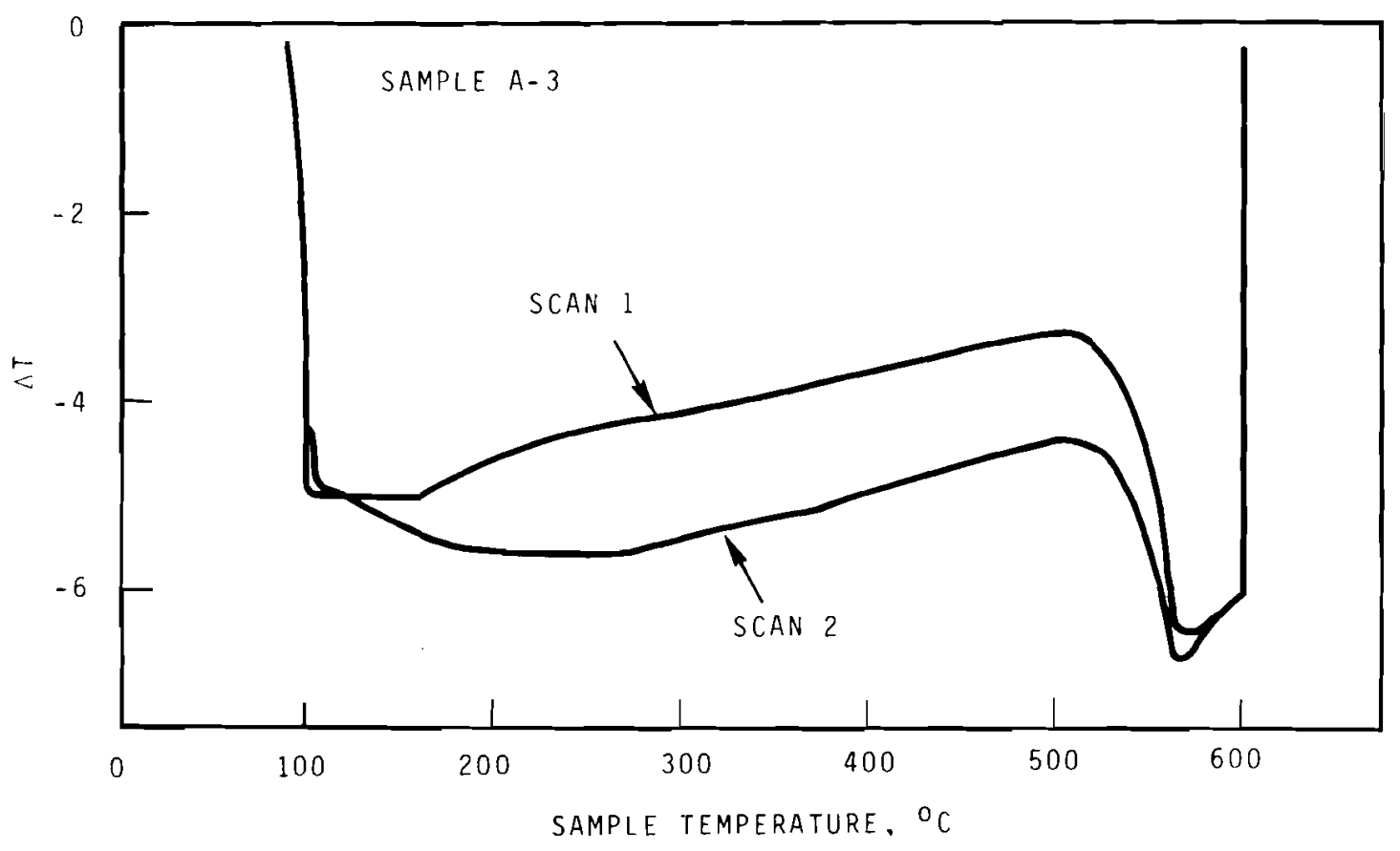

FIGURE 5. Typical Scan for Stored Energy Measurements 


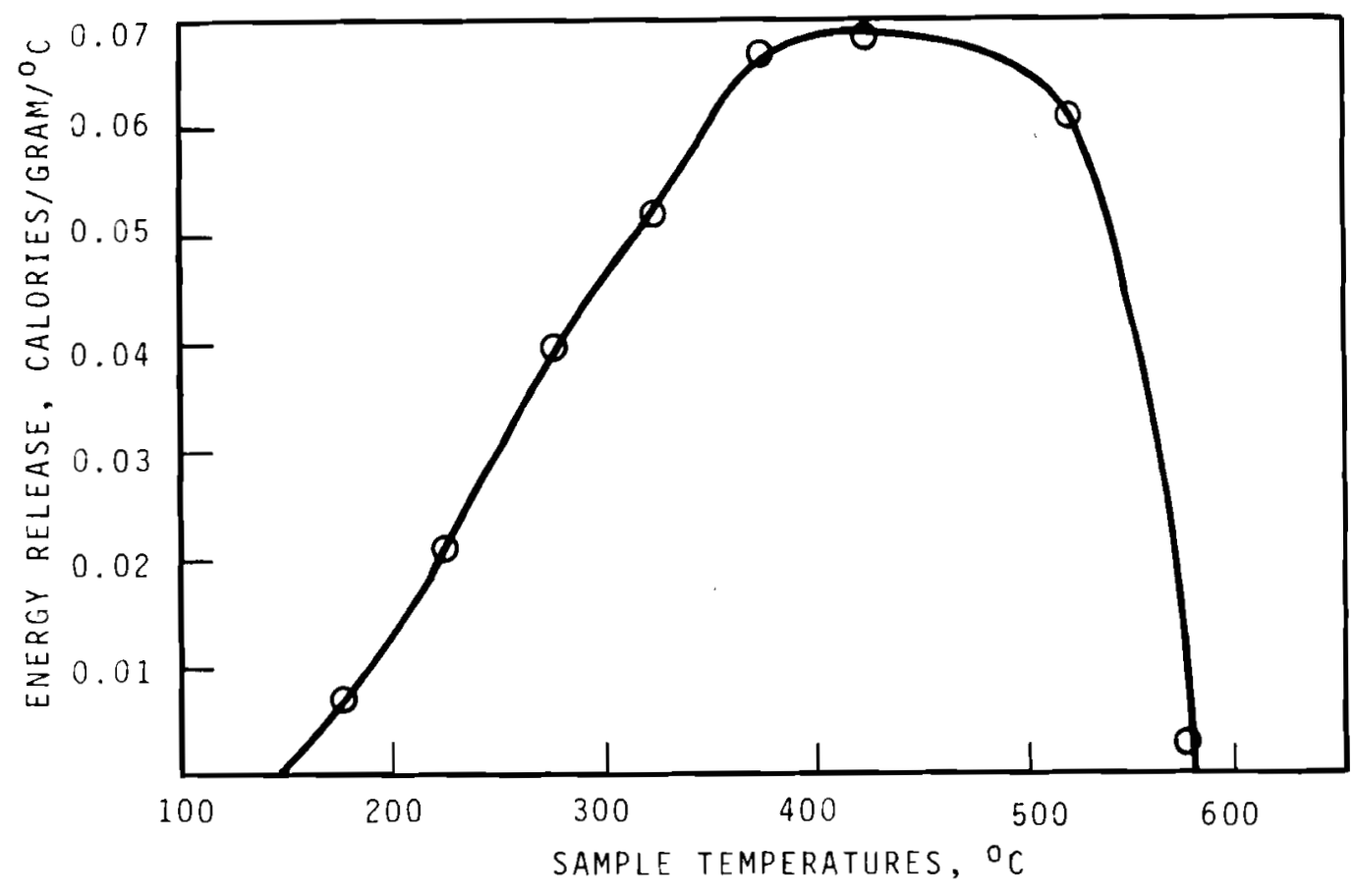

FIGURE 6. Energy Release Rate - Specimen SEN-4

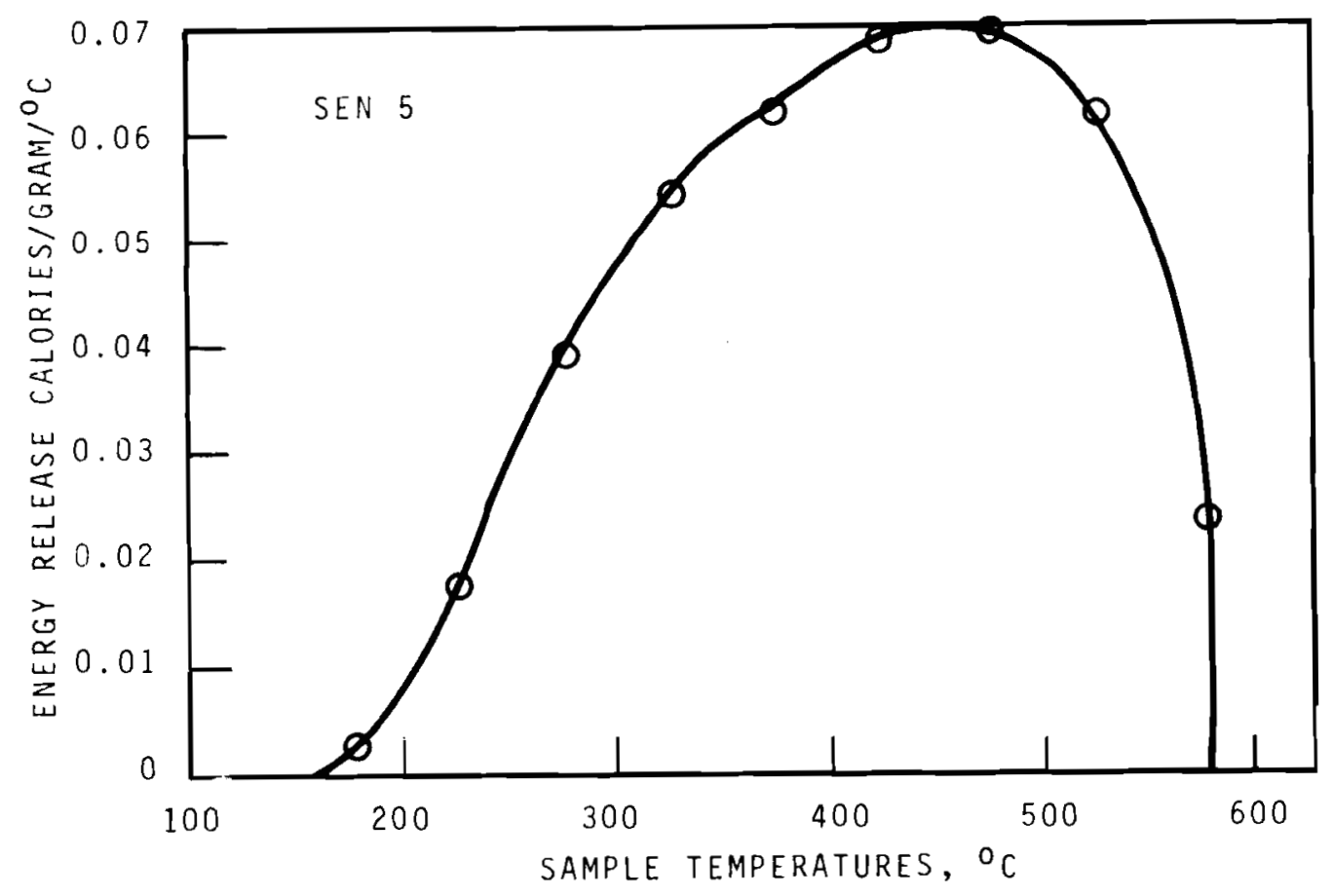

FIGURE 7. Energy Release Rate - Specimen SEN-5 
BNWL-1871

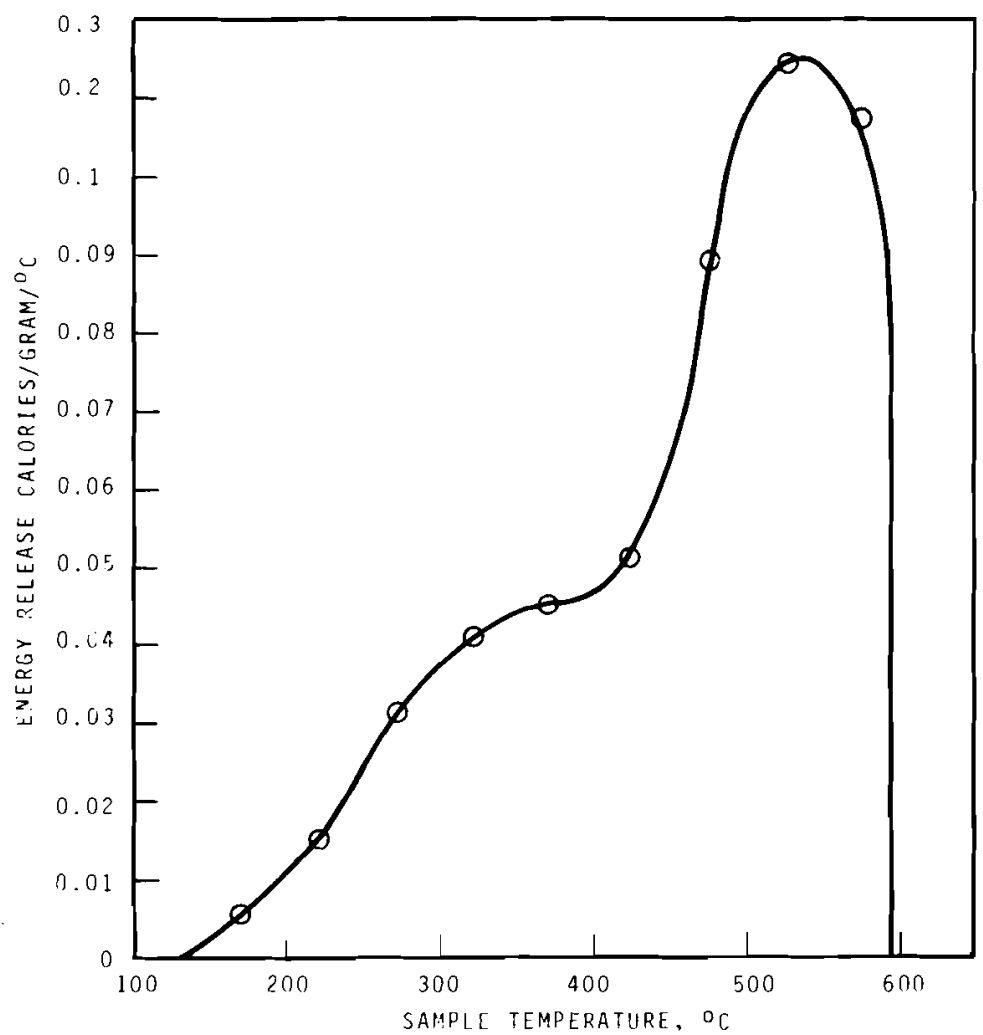

FIGURE 8. Energy Release Rate - Specimen SEN-7

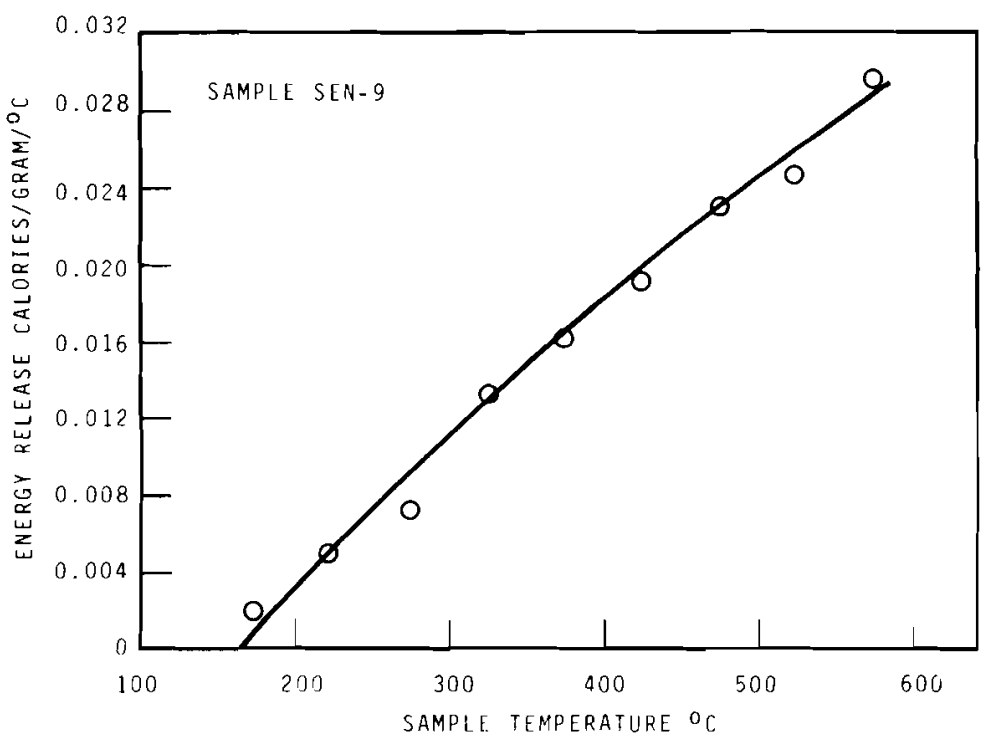

FIGURE 9. Energy Release Rate - Specimen SEN-9 


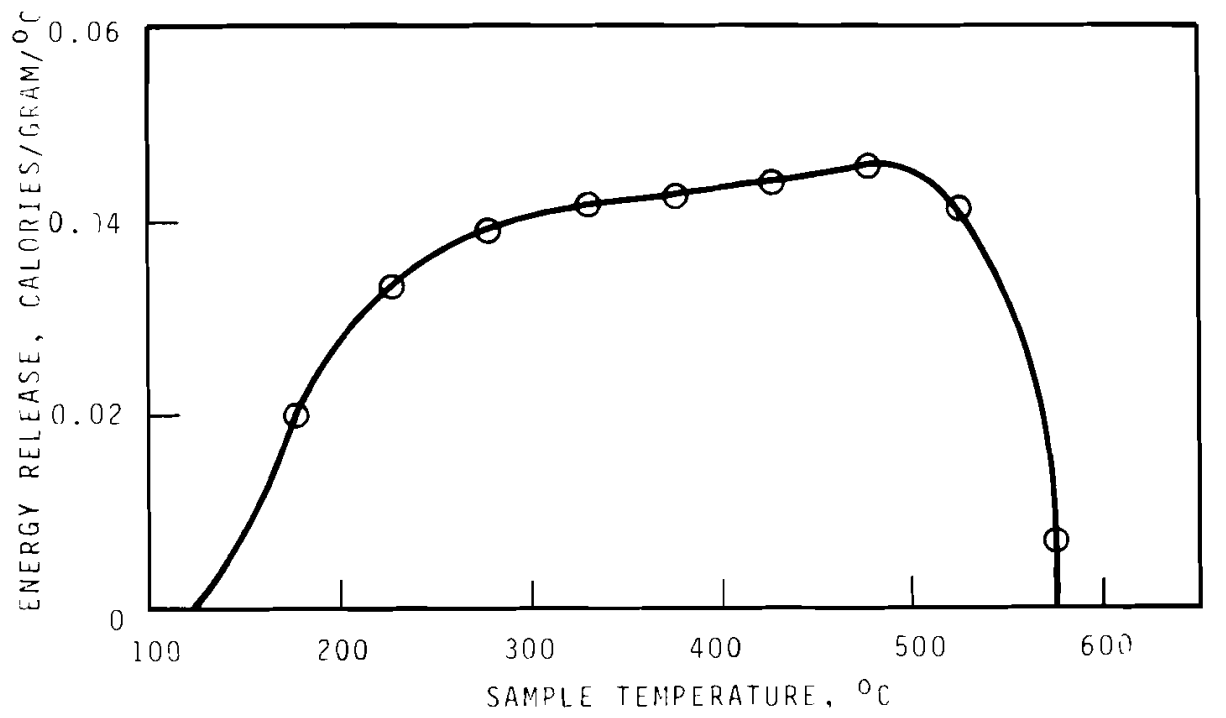

FIGURE 10. Energy Release Rate - Specimen A-3

These data show that the initial release starts at temperatures below $150^{\circ} \mathrm{C}$. The rates of release increase with rising temperature and in the cases of the borosilicate glasses go through a maximum and drop to zero below $600^{\circ} \mathrm{C}$. (The borosilicate glasses undergo softening near this temperature.) For the quartz specimen (Figure 10) no maximum is observed within the operating range of the DSC, indicating that the release is not complete at $600^{\circ}$. This is borne out by the data obtained by the drop calorimeter (Table 5).

\section{Future Work}

Work is under way to experimentally determine the buildup rate of stored energy as a function of storage time at various temperatures. From this, self-arnealing ard other effects will be observed. 
HELIUM IN GLASS - R. P. Turcotte

The objective of this study is the determination of helium diffusion coefficients and temperature dependence in simulated waste glass of the 72-68 composition. An assessment of radiation damage effects is of primary interest; toward this end ${ }^{244} \mathrm{Cm}$ doped glass will be examined. During the past quarter, the effort has been preparative arid directed toward fabricating curium-doped samples in thin discs, performing some initial gas release experiments, and examining thermal devitrification by x-ray diffraction methods.

Thirteen small buttons with 1 wt\% $\mathrm{CmO}_{2}$ have been poured and are currently being pressed into 1 inch discs in a graphite mold. After vacuum outgassing at $500^{\circ} \mathrm{C}$, the discs will be stored and release behavior studied as a function of time. For purpose of comparison, release from several of the discs will be measured immediately after fabrication by prior equilibration with 1 atmosphere of helium.

Several preliminary experiments of this sort have been conducted on undoped buttons. Eight grams of glass in the form of small buttons were equilibrated for $24 \mathrm{hrs}$ with 680 torr helium at $540^{\circ} \mathrm{C}$ and then cooled. After vacuum outgassing the quartz sample tube, gas release was measured using a microcapacitance manometer. The curve obtained is given in Figure 11 for a 1 inear heating rate of $200^{\circ} \mathrm{C} / \mathrm{hr}$. A similar experiment but with isothermal equilibration and release at $400^{\circ} \mathrm{C}$ gave a helium solubility of $\sim 5 \times 10^{-4} \mathrm{cc}($ STP $) / \mathrm{Cc}$ glass. Both the release temperatures and this solubility estimate are within the range expected.

Analysis of the thermal devitrification process at $750^{\circ} \mathrm{C}$ has been examined since a strong dependence of diffusivity on crystallinity is well known. The low angle x-ray diffraction traces of the vitreous and devitrified forms of glass 72-68 are given in Figure 12. The primary crystalline phase is of the $\mathrm{Zn}_{2} \mathrm{SiO}_{4}$ structure type, on which basis a number of the reflections have been indexed. Using the (220), (140), and (223) peaks and an internal standard of $1 \mathrm{wt} \% \mathrm{ThO}_{2}$, relative intensities were measured as a function of time. As shown in Figure 13, 
approximately five days at $750^{\circ} \mathrm{C}$ are required for maximum devitrification. This is fortunately long compared to the disc fabrication time of $21 / 2$ hour, and little devitrification is expected. Curium-doped samples will later be examined for indication of radiation-induced devitrification and compared to the thermal crystaliization. Thermally devitrified samples witl also be prepared, based on these results (Figure 13) and diffusivity compared to the vitreous form.

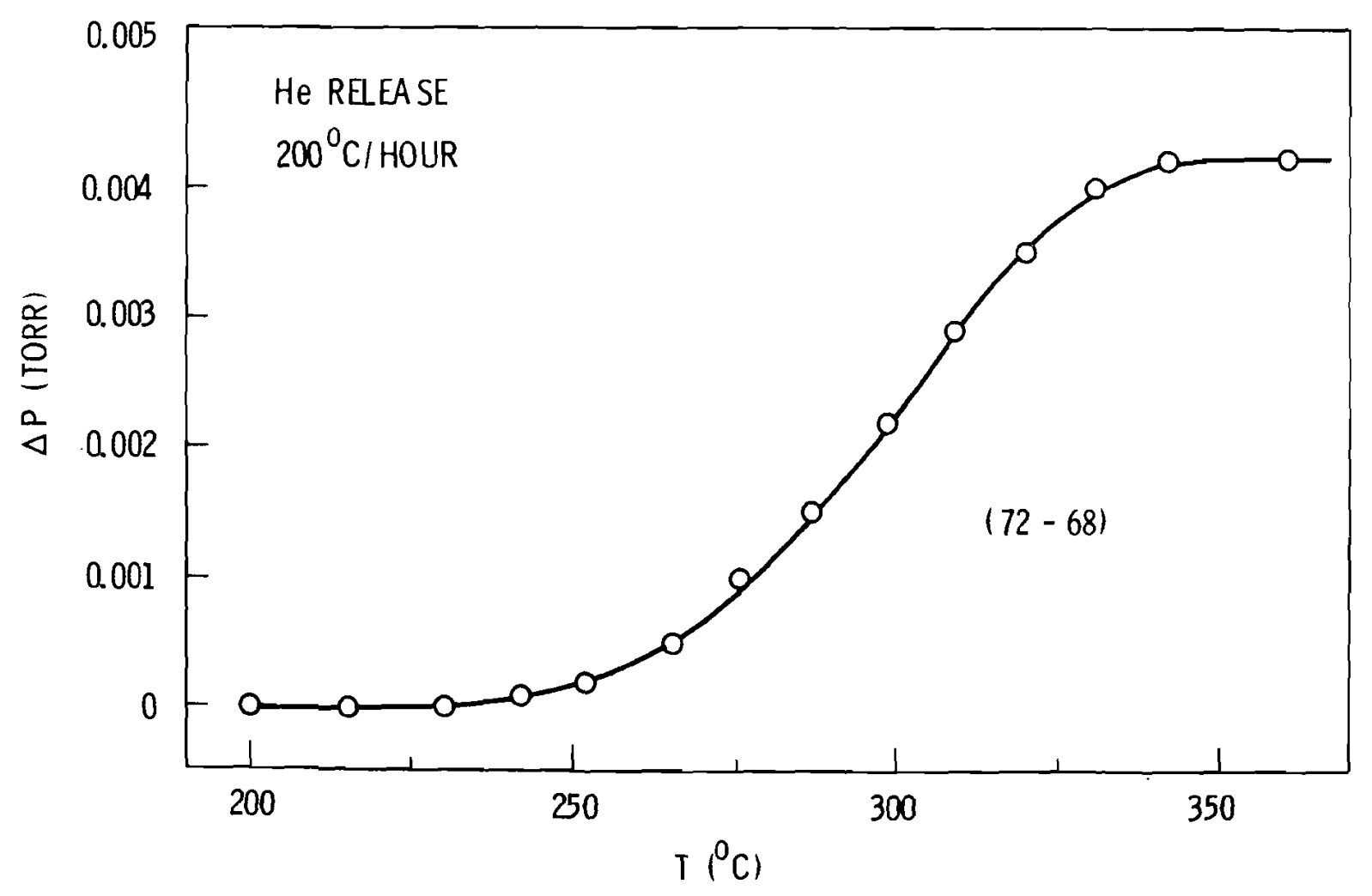

F.IGURE 11. Helium Release from a Sample Equilibrated at $540^{\circ} \mathrm{C}$ for 24 Hours with 680 Torr Helium 
BNWL-1871

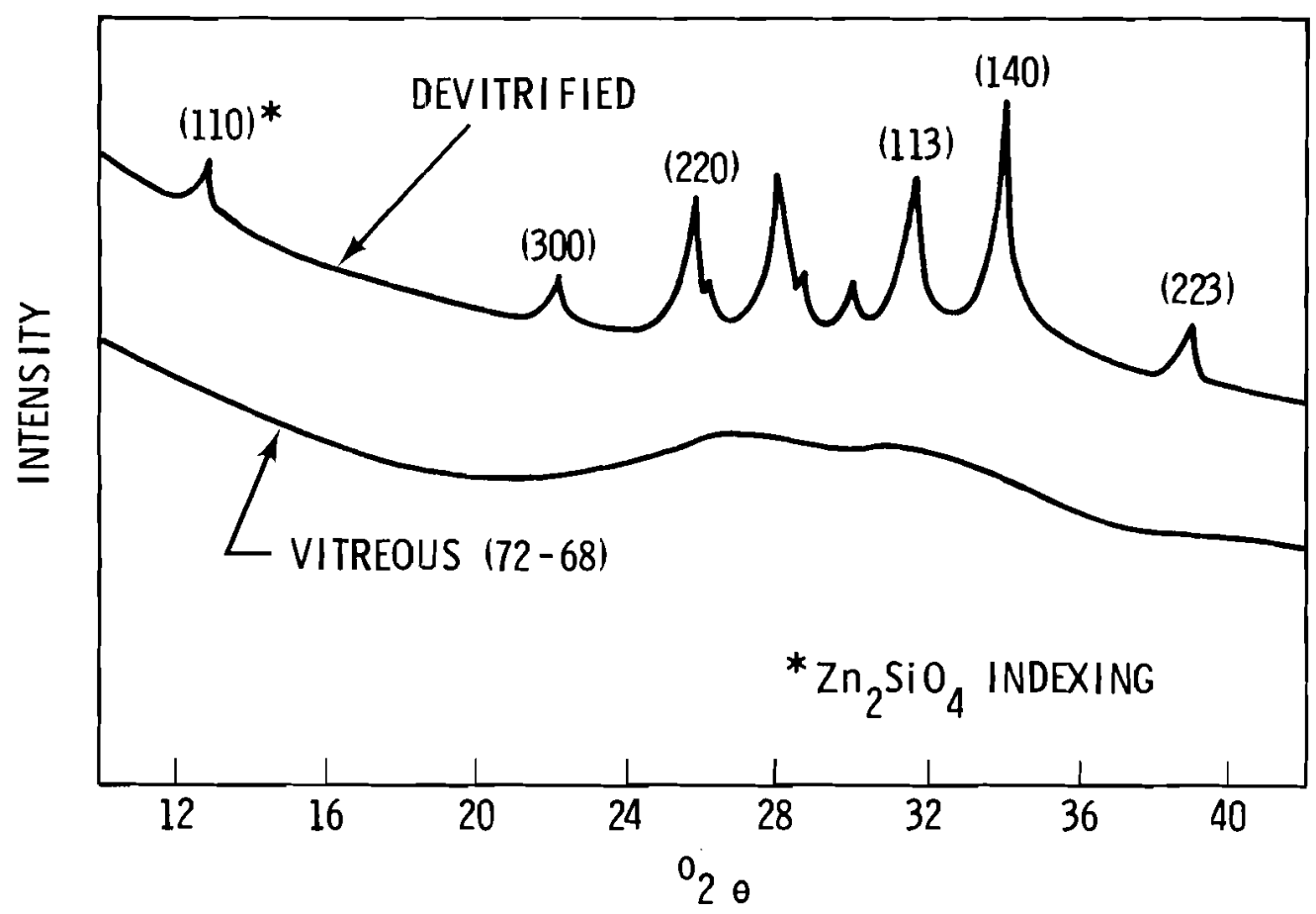

FIGURE 12. Vitreous and Devitrified (5 days $\left.-750^{\circ} \mathrm{C}\right)$ X-ray Diffraction Patterns for Glass $72-68$

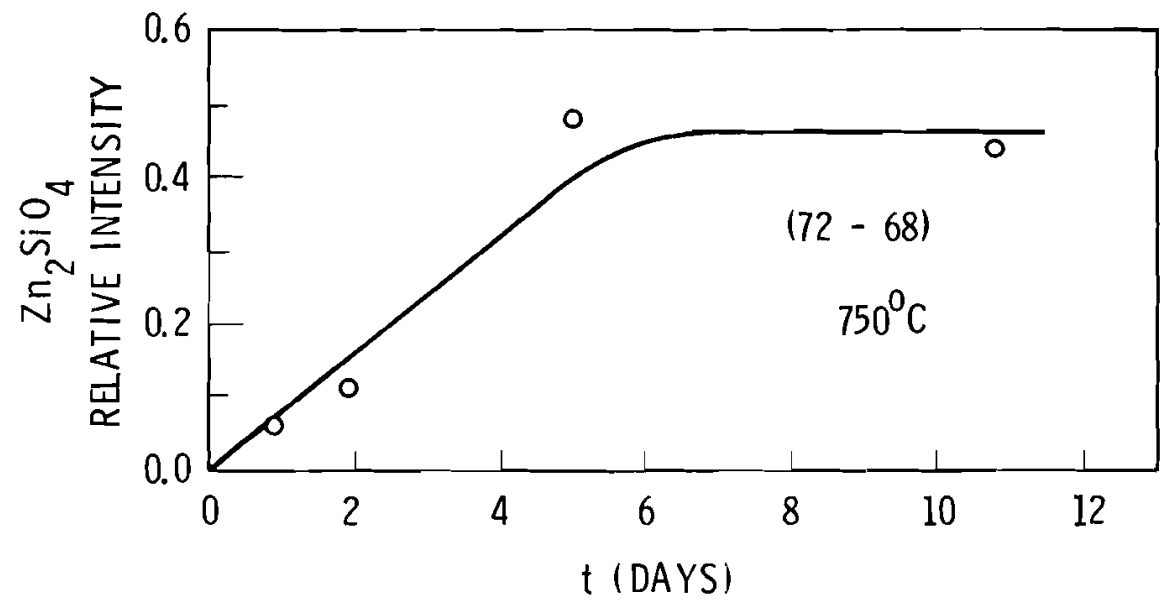

FIGURE 13. Zinc Orthosilicate Diffraction Intensity in Glass 72-68, Plotted as Intensity Versus Time at $750^{\circ} \mathrm{C}$ 
RADIOLYTIC GAS GENERATION - W. D. Felix and G. L. Tingey

Prediction of the gas-solid equilibrium conditions in calcine waste containers is dependent on the measurement of the amounts of gas adsorbed under a variety of conditions. Since adsorption of gases on the calcined surface occurs both by physical and chemical processes, the nature of the adsorbing surface is important. Irradiation of the calcined surface by radioactive waste materials bound to it is expected to modify the surface by the introduction of lattice dislocations, active site generation, and solid matrix-gaseous bond disruption. A critical assessment will be made of the nature of the calcine waste surface and the interaction with gases initially present and with gases introduced by thermal radiation-induced reactions.

A vacuum system has been adapted for conducting measurements of sorption isotherms on calcined nuclear waste. A canacitance manometer has been installed which will allow accurate measurements at pressures in excess of one atmosphere. An accurate determination of the quantity of gas sorbed and easy adjustments of the pressure are acconmodated by the use of a mercury-driven gas burette.

A well documented sample (PW-4b) has been separated into narrow particle size fractions and wi11 be further characterized for these measurements. Sorption isotherms for $\mathrm{H}_{2} \mathrm{O}, \mathrm{H}_{2}, \mathrm{O}_{2}, \mathrm{~N}_{2}$, and $\mathrm{NO}$ will be determined during the next quarter.

\section{WASTE VAPORIZATION STLIDIES - W. J. GraY}

The purpose of this study is to investigate the vaporization behavior of fission product-containing wastes during processing, shipment, and storage. Accident conditions involving high temperature and breach of the container during shipment and storage are of particular interest. 
Analytical results for vapors deposited on a cold finger from samples of 73-167 glass heated at $1200^{\circ}$ and $1000^{\circ} \mathrm{C}$ in dry air are shown in Figures 14 through 17. These results were obtained in the following manner. Vapors were collected on a cold finger after 2, 6 and $16 \mathrm{hr}$ of heating at $1200^{\circ} \mathrm{C}$ and after $12 \mathrm{hr}$ of heating at $1000^{\circ} \mathrm{C}$. The vapor deposits were then dissolved using the same procedure developed ${ }^{(a)}$ for dissolving the glass itself. The resulting solutions were analyzed by atomic absorption and $x$-ray fluorescent techniques. Specific analyses were run only for those elements previously found to vaporize from the pure PW-4b calcine ${ }^{(b)}$ and for some of the glass components. Elements sought, but not detected, are also listed in Figures 14 through 17 . Elements detected were assumed to total to $100 \%$ of the material vaporizing from the samples. Obviously this overestimates the loss via vaporization of these elements because at least some of the vapor species are oxides rather than the pure metals.

Figures 14 and 15 show the percentage weight losses for the individual elements based on the total weight of the glass sample. Figures 16 and 17 show the same data plotted as the percentage of each individual element that is vaporized. The conservative nature of these data is made obvious by Figure 16 where more than 100\% of some elements are shown to be lost. While the amount of conservatism is not known precisely, it can probably be assumed that most of the $C s$ and $T e$ is lost from this thin glass sample after 16 hours at $1200^{\circ} \mathrm{C}$.

Figure 18 shows the effect of moisture on the vaporization of 73-167 glass. In all cases, the flow rate of the air-water mixture was in the range 1 to 3 STP $\mathrm{ft}^{3} / \mathrm{hr}$. While vaporization rates have previously been determined to be independent of dry air flow rates in this range, the scatter in the data here at $1000^{\circ} \mathrm{C}$ indicates this may not be true in moist air. Moisture causes a larger relative increase in vaporization rates at the lower temperatures. At $1200^{\circ} \mathrm{C}$, the effect of increasing moisture content appears to saturate above $5 \%$.

a. Quarterly Progress Report April-June 1974, BNWL-1841, July 1974.

b. Quarterly Progress Report January-March 1974, BNWL-1826, p. 30, April 1974. 
BNWL - 1871

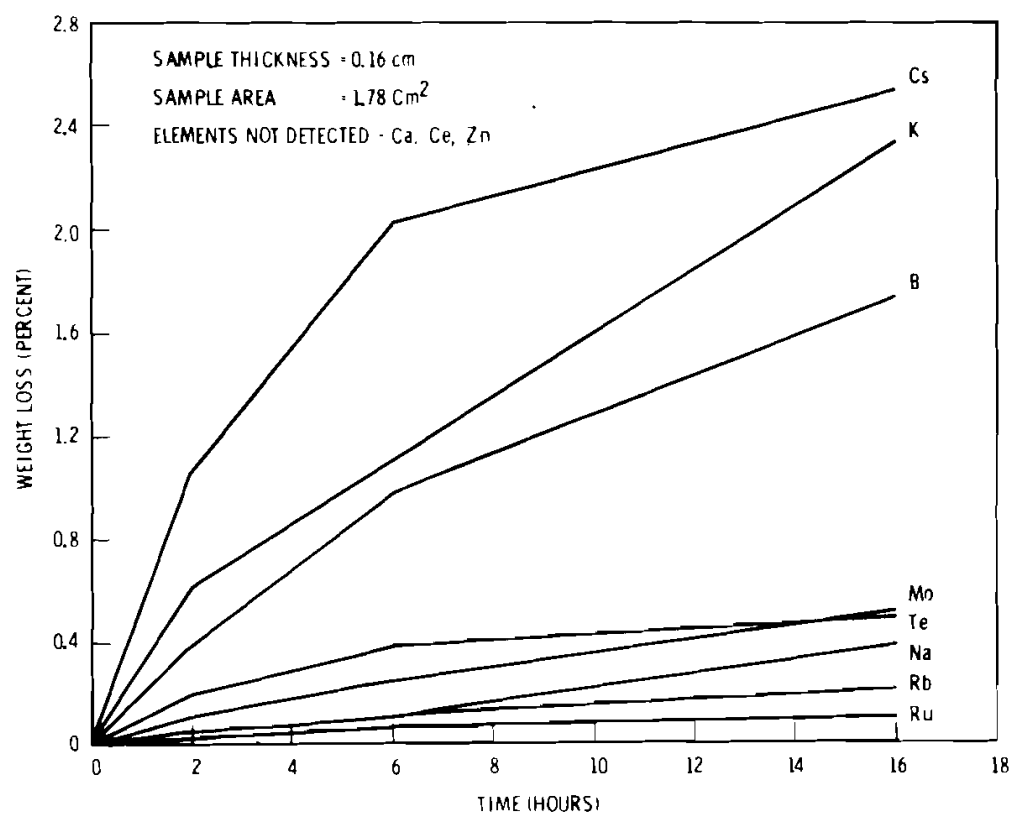

FIGURE 14. Vaporization of $73-167$ Glass at $1200^{\circ} \mathrm{C}$ in Dry Air

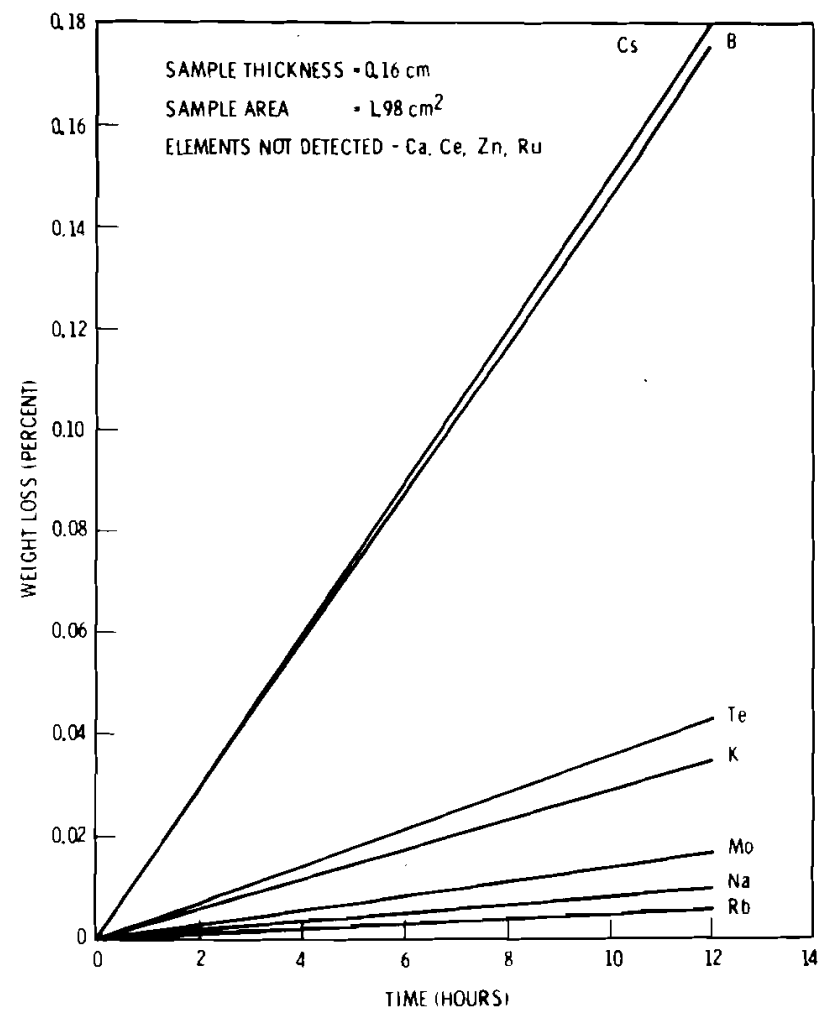

FIGURE 15. Vaporization of 73-167 Glass at $1000^{\circ} \mathrm{C}$ in Dry Air 
BNWL-1871

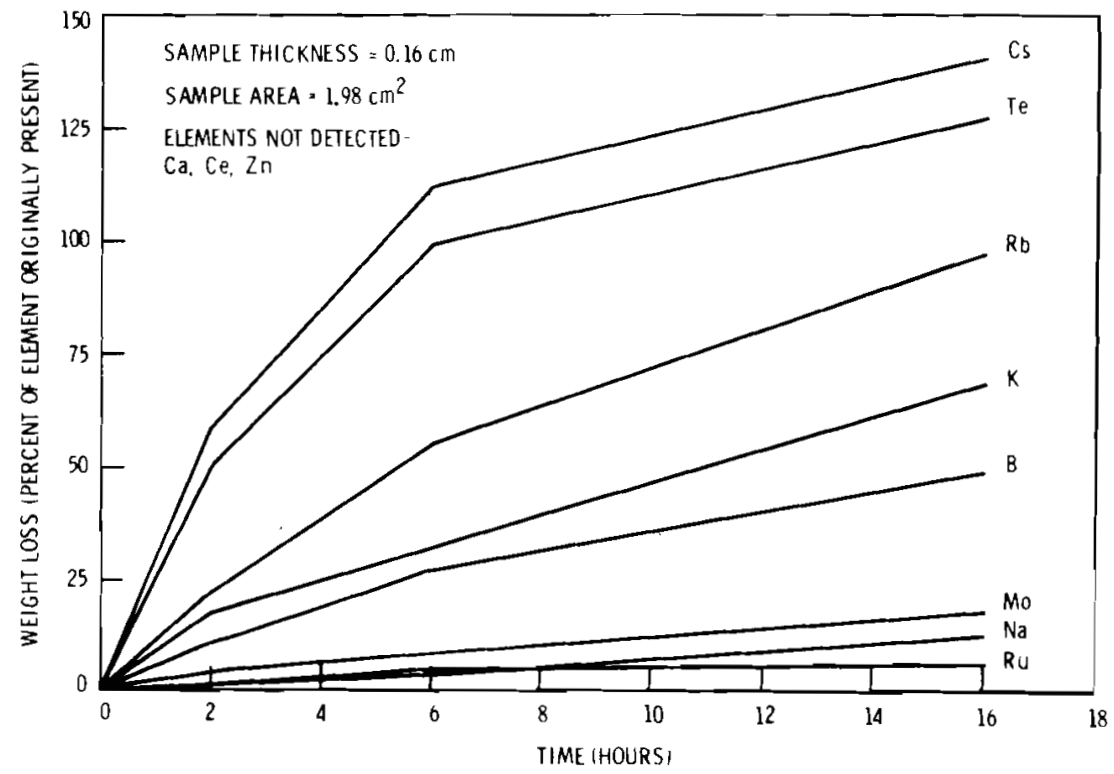

FIGURE 16. Vaporization of $73-167$ Glass at $1200^{\circ} \mathrm{C}$ in Dry Air

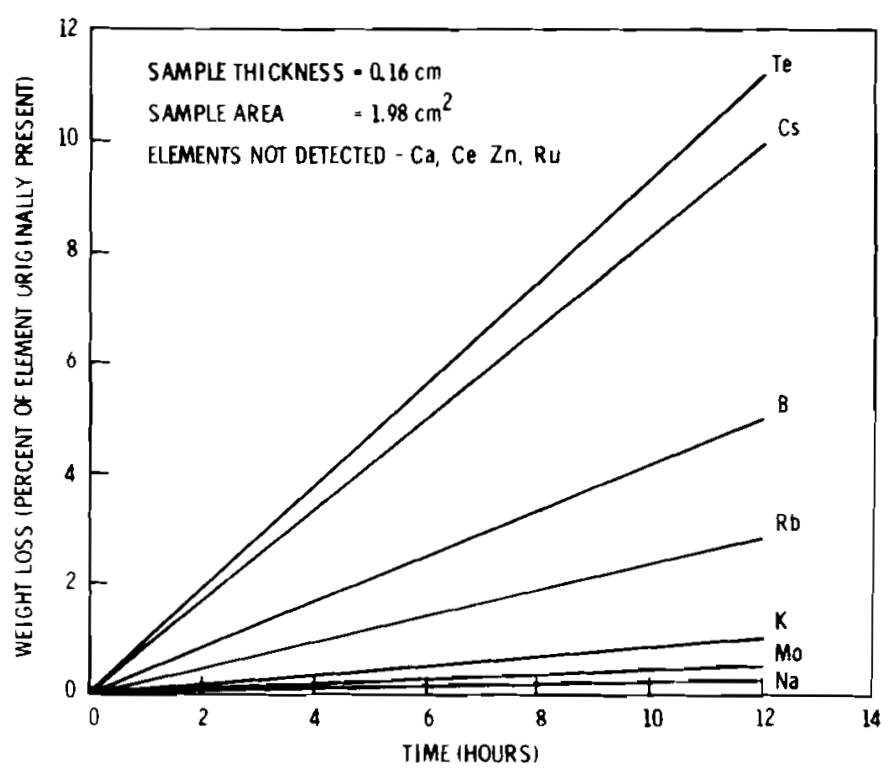

FIGURE 17. Vaporization of $73-167$ Glass at $1000^{\circ} \mathrm{C}$ in Dry Air 
BNWL-1871

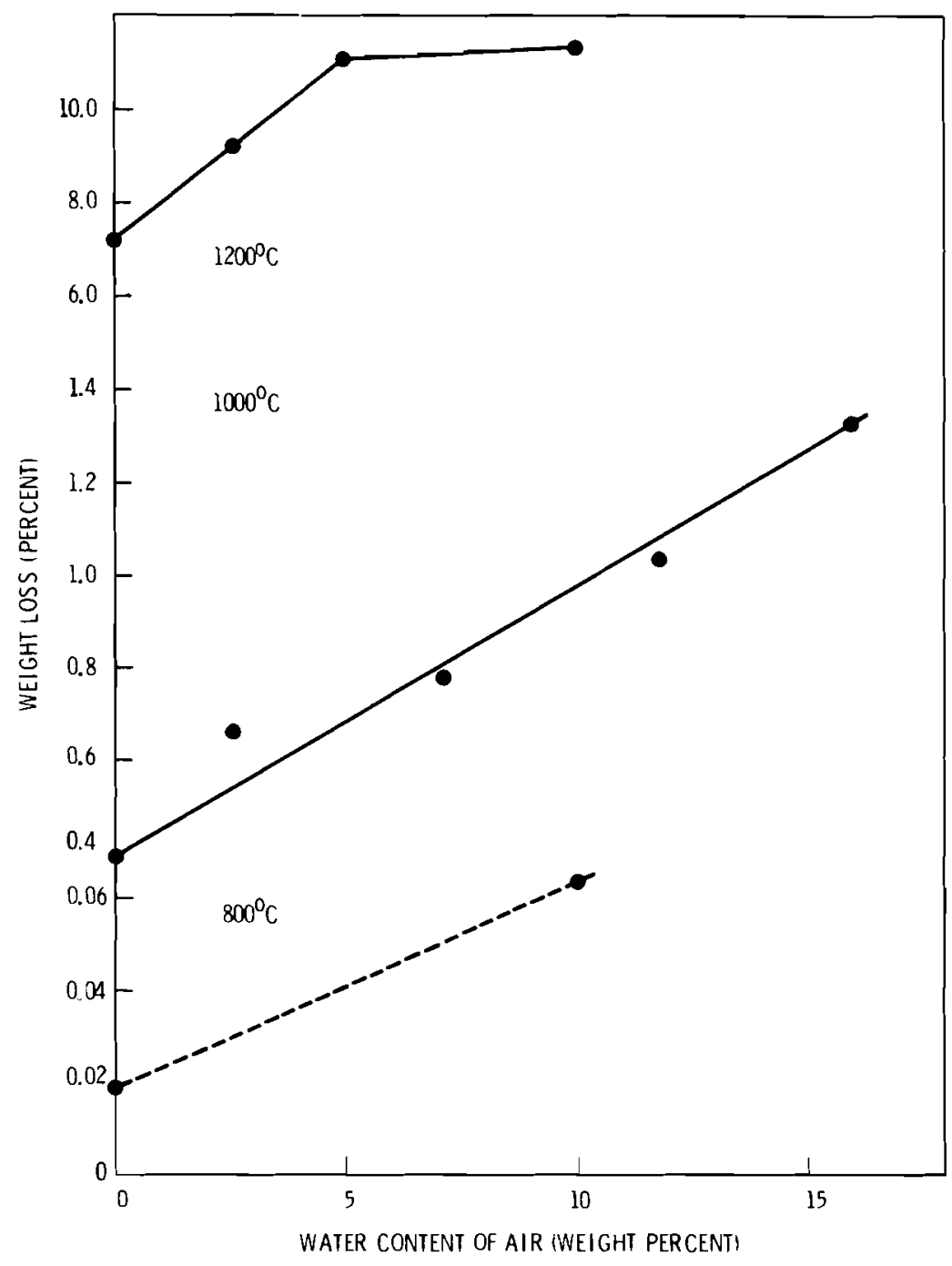

FIGURE 18. Weight Loss from Glass $73-167$ in 10 Hours as a Function of Moisture

Future work will attempt to define the effects of moisture on vapor composition and the effects of sample thickness on vaporization rates. 


\section{ALTERNATIVE WASTE FIXATION SCHEMES}

\section{GLASS SINTERING - W. A. Ross and R. B. Dakan}

Sintering of calcine-glass frit mixtures has the potential to produce a high calcine-containing product at low processing temperatures with good product characteristics. During the quarter, several types of calcine have been tested and their behavior during sintering has been monitored, some processing requirements have been determined, and some product characterization has been performed.

\section{Calcine-Frit Compositions and Behavior}

Glass sintering requires a sufficiently low viscosity $\left(\sim 10^{7}\right.$ poise) to allow the fine particles to flow together. The viscosity is determined by both temperature and glass composition. The particle size of the glass is also important as is shown by the data in Table 6 , which is for a blend of 30 wt\% PW-4b-2 calcine with 73-1 frit ground to the various sizes shown. Pellets were formed from the blends and were sintered at $675^{\circ} \mathrm{C}$ for $2 \mathrm{hr}$.

TABLE 6. Effect of Frit Particle Size on Sintered Density

\begin{tabular}{cr} 
Mesh Size Range & \multicolumn{2}{c}{ Sintered Density } \\
\cline { 2 - 2 }$-40+80$ & 1.83 \\
$-80+100$ & 2.42 \\
$-100+170$ & 2.65 \\
$-170+200$ & 2.78 \\
$-200+270$ & 2.87 \\
$-270+325$ & 3.00 \\
-325 & 3.08
\end{tabular}

The effect of calcine composition and particle size has also been noted in sintering tests. With a $675^{\circ} \mathrm{C}$ sintering temperature, it has been found that $40 \% \mathrm{PW}-4 \mathrm{c}$ spray calcine, 35\% PW-4b spray calcine, $40 \% \mathrm{PW}-4 \mathrm{~b}$ fluidized bed calcine and 50-55\% $\mathrm{PW}-7$ fluidized bed calcine can be incorporated into 
the sintered glass matrix. The fluidized bed materials are coarser than spray calcine and therefore react less extensively with the glass frit in increasing its viscosity. The very coarse calcine ( $>60$ mesh) do not sinter to highest density, however. The reason for this behavior has not been identified.

The sintering behavior of frit-calcine mixtures was determined by a dilatometer method which allowed a qualitative evaluation of the sintering shrinkage to be monitored continuously. The samples were formed into pellets then inserted into a furnace where their length was monitored by a quartz rod and micrometer. The first sample was a 50-50 mixture of 73-1 frit and PW-4b-2 calcine. The sample was heated rapidly $\left(400^{\circ} \mathrm{C} / \mathrm{hr}\right)$ to $500^{\circ} \mathrm{C}$ then more slowly to maximum test temperature. The upper curve in Figure 19 was obtained in the first test. Thermal expansion of the sample and measurement system is shown up to about $650^{\circ} \mathrm{C}$. However, at about 695 to $705^{\circ} \mathrm{C}$ a rapid increase in sample size is noted. Examination of the sample after the heating cycle indicates that the rapid length increase is associated with gas generation in a sealed or partially sealed sample. Above $705^{\circ} \mathrm{C}$ the sample aga in begins to densify. The major sintering appears to be complete at about $750^{\circ} \mathrm{C}$ with length decrease above this temperature probably associated with sample creep or flow.

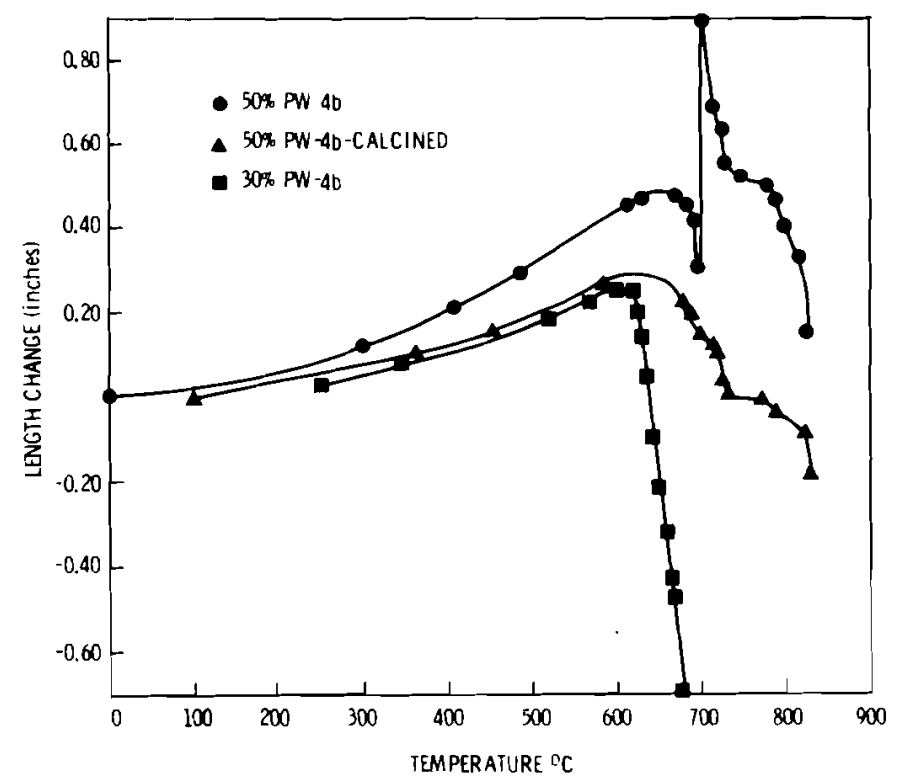

FIGURE 19. Sintering Curves for PW-4b-2 and 73-1 Mixtures 
To avoid bloating the product due to gas formation, pure calcine was recalcined at $800^{\circ} \mathrm{C}$ for 2 hours to remove volatiles before mixing with frit and sintering. The results of this are shown by the center curve. The recalcining was quite successful in removing the major off-gas; however, some flattening of the curve in the $700^{\circ} \mathrm{C}$ region indicates that not all volatiles were removed by the pretreatment.

A thermal galvametric analysis (T.G.A.) of PW-4b-2 calcine and a PW-4b-2 calcine 73-1 frit mixture has indicated that frit and calcine must both be present to produce a rapid weight loss or gas formation at about $705^{\circ} \mathrm{C}$. This data has led to the use of $675^{\circ} \mathrm{C}$ as the maximum sintering temperature. The bottom curve in Figure 19 shows the behavior of a 30\% PW-4b-2 calcine-70\% frit mixture and indicates that the composition and temperature are satisfactory to sinter effectively.

\section{Processing Requirements}

Two basic methods are being considered for forming or processing of the glass-calcine products. The first method is to form shapes by cold pressing then loading the canisters with the various shapes. The second method is to form the product in the canister by hot pressing or some other technique.

Cold pressing of ceramic bodies before sintering is one method of forming a desired shape. A series of tests was performed with the $30 \%-P W-4 b-2$ calcine 70\%-73-1 frit mixture to identify the minimum pressure required for a high density product. The first series of pellets was formed at pressures from 680 to 22,600 psi in steel compaction dies. The second and third series were prepared by loading powder into a stainless steel beaker then compacting with a rarn and sintering in the beaker since the pellet or compact lacked sufficient strength to hold together. Pressing pressures for these series ranged from about 1 psi to $400 \mathrm{psi}$. The pellets were all sintered at $675^{\circ} \mathrm{C}$ with $300^{\circ} \mathrm{C} / \mathrm{hr}$ heatup and cooldown and 2 hours at temperatures.

The data in Table 7 shows that the sintered density is nearly independent of pressing pressure except at high pressures where density appears to 
decrease. The sintered shrinkage, however, does decrease with increasing pressing pressure, as might be expected. High pressing pressures will not therefore be a requirement for the sintered product.

TABLE 7. Effect of Pressing Pressure on Sintered Density

\begin{tabular}{ccc}
$\begin{array}{c}\text { Pressing } \\
\text { Pressure (psi) }\end{array}$ & $\begin{array}{c}\text { Linear } \\
\text { Sintered Shrinkage }\end{array}$ & Sintered Density \\
\cline { 2 - 3 }$\sim 1$ & ND $(a)$ & 3.085 \\
50 & ND & 3.089 \\
100 & ND & 3.081 \\
200 & ND & 3.099 \\
400 & ND & 3.105 \\
680 & 16.0 & 3.087 \\
1130 & 15.3 & 3.086 \\
2260 & 14.4 & 3.087 \\
4530 & 13.3 & 3.086 \\
11300 & 10.9 & 3.077 \\
22600 & 7.9 & 2.981
\end{tabular}

a. ND - Not Determined

Hot pressing involves the simultaneous application of heat and pressure. The pressure required for filling canisters is only that necessary to deform the material during sintering. Tests with small cylinders (0.660 in. diam.) have shown that $12 \mathrm{psi}$ is sufficient to form a pellet which is in complete contact with the canister walls. Wall friction, however, has 1 imited the depth to which pressure applied to the upper surface will act on a sintering mass. Tests with the $0.660 \mathrm{in}$. dia beaker have indicated that a length to diameter $(L / D)$ ratio of 2.1 can be obtained with 12 psi. A higher pressure of 22 psi produced a pellet with a $2.9 \mathrm{~L} / \mathrm{D}$ ratio. This indicates that canisters either can be filled in steps or much higher pressures can be used. The low pressures are desirable since they can be obtained simply with static weights. 
The most significant obstacle to the progress of this waste form is achieving a workable technique for forming a sintered product in the final waste storage canister which is not loose in the can after it has densified. One possible solution is to use a zone sintering technique whereby pressure is applied to the zone which is sintering, forcing it to flow outward to the walls as it densifies, filling the canister. The possibility of using calcine waste storage canisters for in-can sintering is remote, due to the probable presence of cooling fins within the can. This problem does not arise if sintering is done at the reprocessors.

\section{Material Characteristics}

The sintered pellets appear to have good physical properties. They are quite dense, generally about $3.06 \mathrm{~g} / \mathrm{cc}$ where $72-68 \mathrm{glass}$ is about $3.24 \mathrm{~g} / \mathrm{cc}$, indicating that the pellets are about $94 \%$ of maximum density. A Mercury porosimeter indicated that the $6 \%$ porosity is nearly all closed; for up to 5000 psi there was less than $1 \%$ open porosity. The microstructure shown in Figure 20 also indicates that the porosity (black areas) is quite spherical. The micrograph also shows the uniform distribution of the calcine (white areas) in the glass matrix (gray areas). The large crystals have been identified as nearly pure $\mathrm{SiO}_{2}$, probably residual stones in the frit.

Leach tests have been made on the $30 \%$ PW-4b-2 pellets by the accelerated Soxhlet method. The pellet leached at a rate about $11 / 2$ to 2 times that of 72-68 glass. The low leach rate indicates that the calcine is reacting to some degree with the frit and is not just being incorporated into the matrix.

$X$-ray diffraction analyses do now show any crystal structures in the PW-4b-2 sintered pellets, indicating that devitrification will not be a problem.

The pellets were tested for residual $\mathrm{NO}_{x}$ which may decompose by radiolysis, but the analysis did not detect any at its $10 \mathrm{ppm} 1 \mathrm{imit}$. Further characterization and process development is planned for the glass sintering process. 


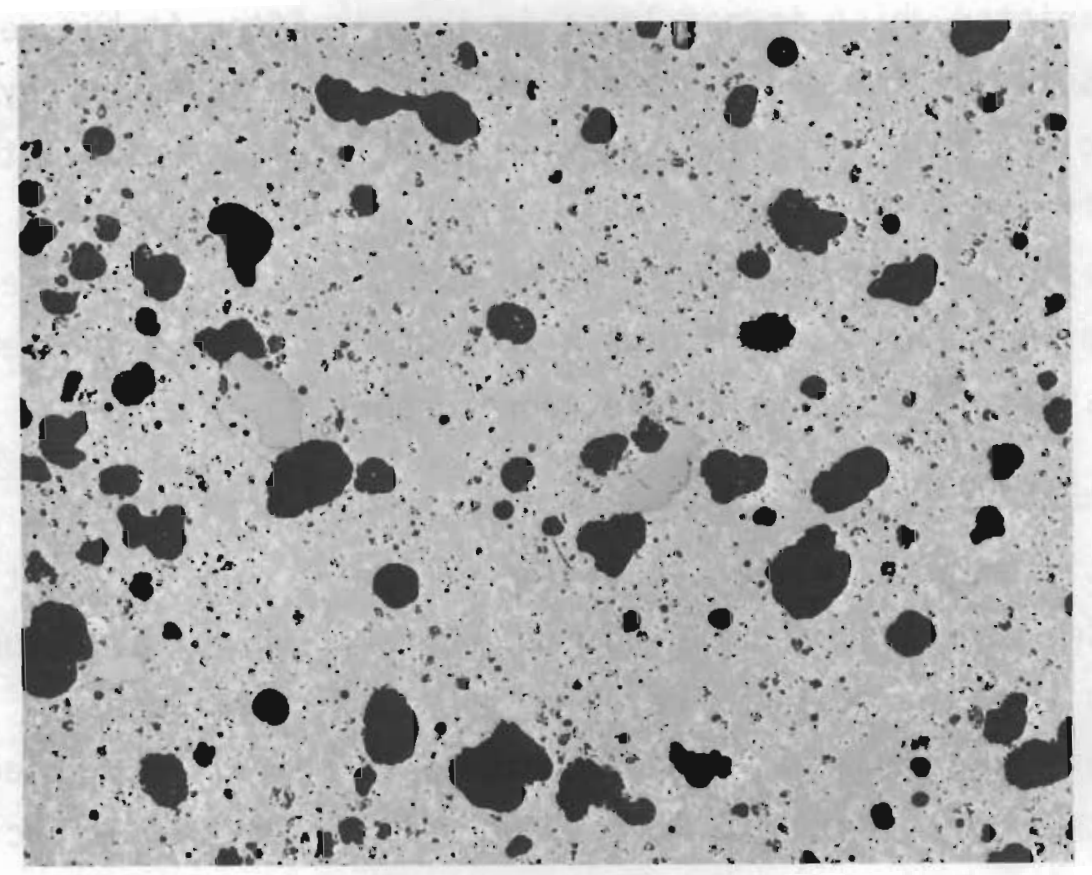

\section{FIGURE 20. 100X Photomicrograph of a Sintered Pellet Containing $30 \% \mathrm{PW}-4 \mathrm{~b}-2$ Calcine and $70 \%$ 73-1 Frit}

\section{CARBON AND SIC COATED WASTE PARTICLES - W. J. GraY}

The purpose of this study is to characterize waste particles coated with pyrolytic carbon (PyC) or PyC and SiC, to investigate methods of encapsulating the coated particles in a matrix, and to develop process methods for coating and encapsulating the waste.

Figure 27 shows PyC coated waste particles encapsulated in an aluminum matrix prepared as follows. Waste particles were placed in a stainless steel crucible, and aluminum pellets were placed on top of the particles. This was heated to $700^{\circ} \mathrm{C}$ in a vacuum, backfilled to about 50 psi He gas pressure and then cooled. The molten aluminum wets the walls of the crucible, providing a seal so that pressurizing with He forces the aluminum into the interstices between the particles. 


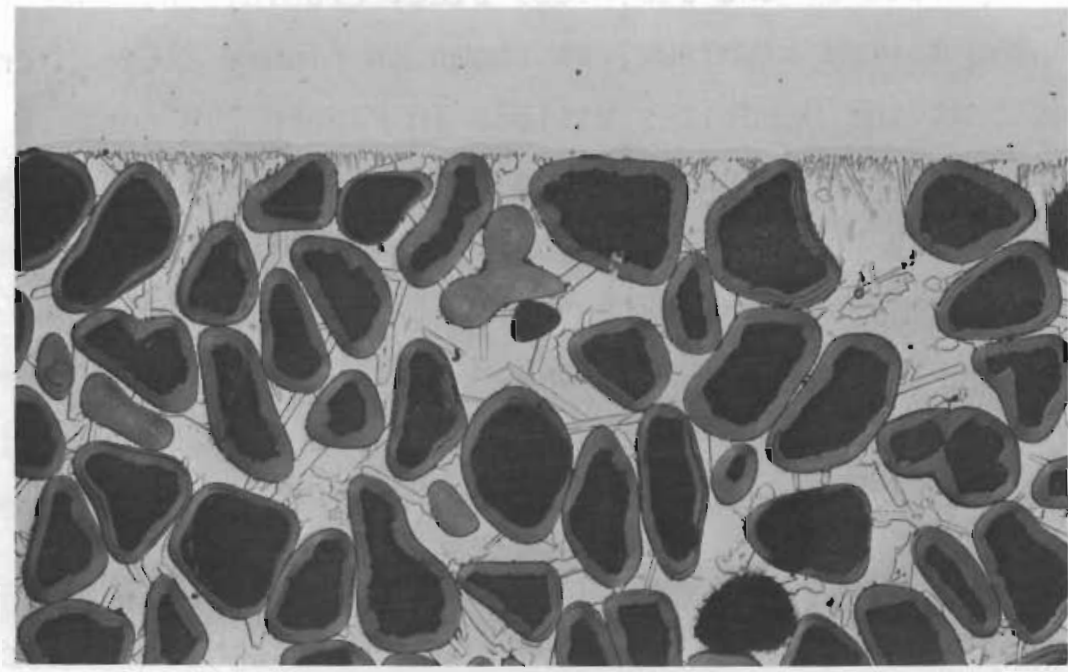

뭄

중

o

- ำ

อ

ชิ

का $\frac{\pi}{3}$

x-

$+\frac{10}{4}$

$\sum^{\pi} \backsim$

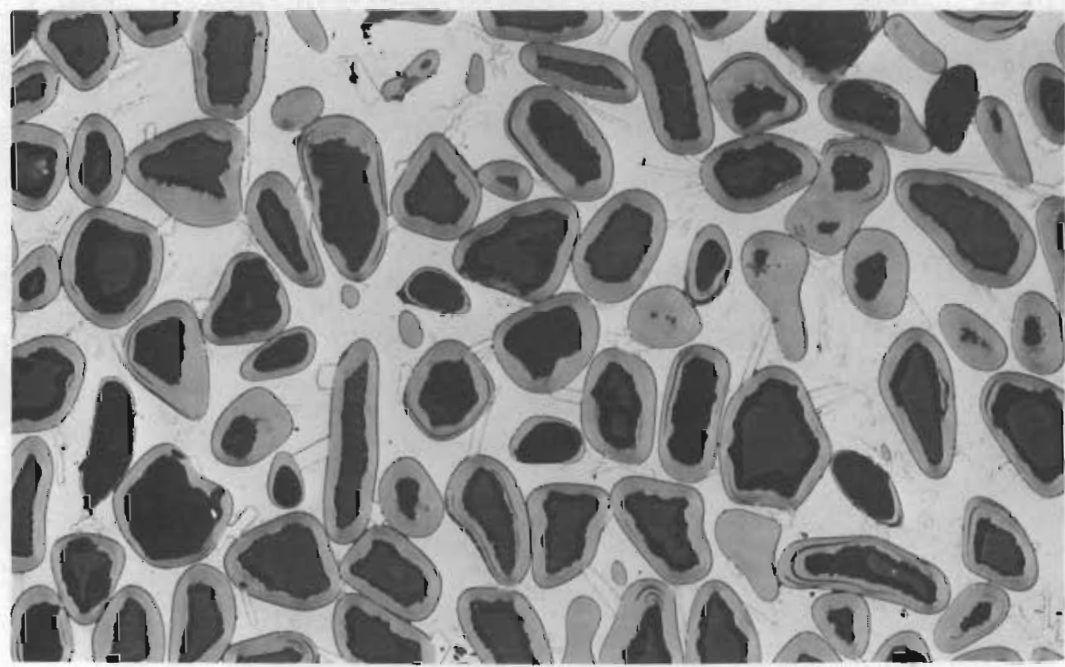

๘

$=\sqrt{5}$

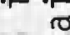

可点

- $\quad$ 告市

을

है।

능

동

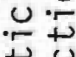

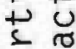

ช

$\stackrel{90}{\square}$

$\stackrel{\oplus}{\sim}$

$\frac{\pi}{3} \frac{3}{0}$

它

$\stackrel{0}{+1}$

동

0

\ن

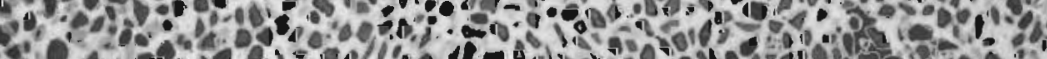
A. 100 y 0 100 - 80 o

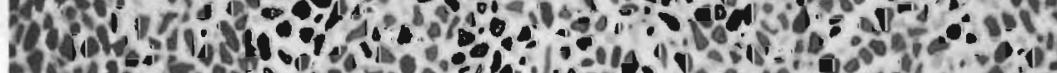

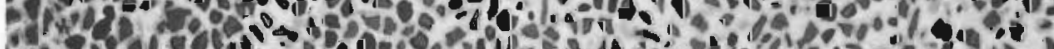

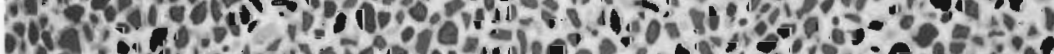

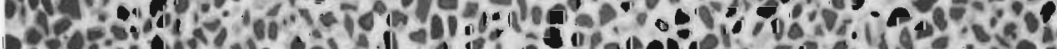
Boc.

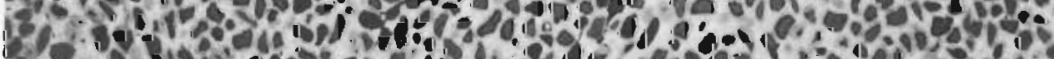

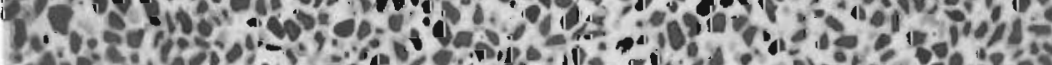

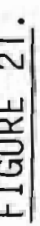


The inner surface of the stainless steel crucible has been corroded by reaction with the molten aluminum, as shown in Figure 21C. Microprobe analysis shows that the dendrites visible in Figure 21B contain a lot of iron, chrome, and nickel (perhaps approaching $50 \%$ in tota 1 ). Nevertheless, the matrix looks very good. All the particles are well contained, the particle density is good, and there is very little porosity in the matrix. Since iron is sometimes added to aluminum castings to reduce shrinkage, it is likely that the reaction with the crucible benefits the matrix by preventing shrinkage cracks and pores that would otherwise be formed.

This encapsulation technique looks attractive for a large-scale process. The temperatures and pressures required are low enough to be easily and cheaply attained. Some corrosion of the inner surface of the storage canister can likely be tolerated, since it will occur only during the melting and impregnating steps. If the amount of corrosion is found to be intolerable, an inert coating or liner for the canister can be used.

A second leach test has been performed on waste particles coated with PyC and PyC/SiC to confirm and improve the reproducibility of the results from an earlier test. ${ }^{(a)}$ Results after three 24-hour leach periods using the Soxhlet Leach Test are:

\begin{tabular}{|c|c|c|}
\hline & \multicolumn{2}{|c|}{ Wt\% Loss } \\
\hline Time & PyC & Pyc/Sic \\
\hline Ist 24 hours & -0.03 & -0.02 \\
\hline 2nd 24 hours & -0.01 & -0.03 \\
\hline 3rd 24 hours & -0.03 & -0.02 \\
\hline Total & -0.07 & -0.07 \\
\hline
\end{tabular}

These results are much more reproducible than before ${ }^{(a)}$ and confirm that the leach rates are low compared with Pyrex glass which loses $0.55 \mathrm{wt} \%$ after a 72-hour Soxhlet Leach Test. ${ }^{(b)}$

a. Quarterly Progress Report, January-March 1974, BNWL-1926, p. 41 , Apri1 1974.

b. Quarterly Progress Report, BNWL-1741, p. 4, Apri1 1973. 
VITREOUS CARBON WASTE CONTAINMENT - L. R. Bunnel1

Radiation Stability

Work done previously indicated that vitreous carbons could be an attractive alternative to glass as waste containment. A potential barrier to its use is the radiation stability of the resin before conversion to pure carbon. During this period, the resin would be subjected to very intense alpha, beta, and gamma radiation. To observe the effects of irradiation, discs of catalyzed polyfurfuryl alcohol resin $(a)$ were cast. These discs were subjected to alpha and gamma irradiation, then carbonized to $1000^{\circ} \mathrm{C}$ in $150 \mathrm{hrs}$ under vacuum. Table 8 summarizes the results. Metallographic examination of carbonized specimens 3 and 7 showed no cracking or evidence of degradation. The gamma doses accumulated by the specimens are of the order of $10^{9}$ rads. One additional disc is undergoing irradiation at present and will be carbonized after accumulating about $10^{11}$ rads. Additional alpha irradiations will also be performed.

a. Quaker 0ats RP100A resin, catalyzed with 4 wt\%,RP104B catalyst.

\section{TABLE 8. Results of Resin Irradiation Experiment}

\begin{tabular}{|c|c|c|c|c|c|}
\hline $\begin{array}{l}\text { Sample } \\
\text { No. }\end{array}$ & $\begin{array}{l}\text { Irradiation } \\
\text { Treatment } \\
\end{array}$ & $\begin{array}{c}\text { Post- } \\
\text { Irradiation } \\
\text { Appearance } \\
\end{array}$ & $\begin{array}{c}\text { Irradiation } \\
\text { Weight Ga in } \\
(10 \mathrm{~s}), \% \\
\end{array}$ & $\begin{array}{c}\% \text { Wleight } \\
\text { Loss on } \\
\text { Carbonization } \\
\end{array}$ & $\begin{array}{c}\text { Appearance } \\
\text { after } \\
\text { Carbonization } \\
\end{array}$ \\
\hline 3 & $\begin{array}{l}\alpha \text { irradiated } \\
24 \times 10^{14} \\
\text { particles } / \mathrm{cm} \\
\text { from }{ }^{238} \mathrm{PuO}_{2}\end{array}$ & Excellent & 0 & 39.7 & Excellent \\
\hline 4 & None (control) & NA & NA & 39.8 & Excellent \\
\hline 5 & $\begin{array}{l}\text { y irradiated } \\
2.68 \times 10^{8} \mathrm{rad}\end{array}$ & Excellent & $2 \%(a)$ & 40.1 & Excellent \\
\hline 6 & $\begin{array}{l}\text { y irradiated } \\
1.35 \times 10^{7} \mathrm{rad}\end{array}$ & Excellent & $0.6 \%^{(a)}$ & 40.0 & Excellent \\
\hline 7 & $\begin{array}{l}\gamma \text { irradiated } \\
5.64 \times 10^{9} \mathrm{rad}\end{array}$ & Excellent & $(3.6 \%)^{(a)}$ & 40.4 & Excellent \\
\hline
\end{tabular}

a. Variable weight gain or loss probably because of water sorption/desorption in gamma facility. 
BNWL -1871

\section{Particle Size Limitations}

Since precursor resins typically shrink as much as $20 \%$ in each direction during carbonization, there is a finite size limit for introduced particles. Particles above this limit cause matrix cracking. Because all work to date has been done with -400 mesh PW-4b calcined simulated waste, the upper size limit is not known. An experiment was carried out in which discs were made containing 40 to $50 \mathrm{wt} \%$ of waste, either as calcined waste or as larger, pyrolytic carbon coated particles. As shown in the Table 9, neither size of coated particle was accommodated. Additional experiments were performed with calcined waste batches of typical particle sizes to test whether the larger particles present can be accommodated without matrix fracture.

\section{TABLE 9. Results of Encapsulation Experiment}

Waste Source

Calcined Waste, Batch PW-4b, $-37 \mu \mathrm{m}$ (Experiment Standard)

PyC - Coated particle Batch 5895-85

(300 $\mu \mathrm{m})$

PyC - Coated particle Batch 5768-141

$(650 \mu \mathrm{m})$
Wt $\%$ waste Wt\% Catalyst

50

40

47

\section{8}

4

4

\section{Comments}

Delayed curing because of catalyst sorption. No cracking, excellent microstructure.

Curing normal, severely cracked during carbonization.

Cure normal, completely disintegrated during carbonization.

\section{Calcine Variations}

Polyfurfural alcohol resin was mixed with several batches of simulated waste, in all cases adding waste until the mixture could just be poured. The purpose was twofold: 1) to determine how well the vitreous carbon would tolerate different chemical compositions and 2) to see if the vitreous carbon would tolerate a normal particle size distribution, since previous experiments were done with -400 mesh materia1. Results are summarized in Table 10. 
TABLE 10. Carbonization of Resin Containing Three Simulated Wastes

\begin{tabular}{|c|c|c|c|}
\hline Waste Type & $\begin{array}{l}\text { Wt\% Waste In } \\
\text { Pourable Mix }\end{array}$ & Curing Behavior & $\begin{array}{l}\text { Appearance after Carbonization, } \\
\text { External and Metallographic }\end{array}$ \\
\hline$P W-4 b$ & 47 & Norma 1 & $\begin{array}{l}\text { Flat, no cracks, metallographi- } \\
\text { cally very good. }\end{array}$ \\
\hline $\mathrm{PW}-6$ & 36 & Normal & $\begin{array}{l}\text { Slight warping, considerable } \\
\text { cracking, but fairly sound } \\
\text { microstructure }\end{array}$ \\
\hline$P W-4 c-7$ & 59 & $\begin{array}{l}\text { Extremely } \\
\text { slow; required } \\
150^{\circ} \mathrm{C} \text { to harden }\end{array}$ & $\begin{array}{l}\text { Severely warped and cracked; } \\
\mathrm{Al}^{0}{ }^{0} \text { particles sank to bottom, } \\
\text { rest of waste graded according } \\
\text { to setting rate, with almost } \\
\text { none at top (concave surface) }\end{array}$ \\
\hline
\end{tabular}

PW-4b is apparently more suitable for containment in vitreous carbon. PW- 6 is much less, apparently because of its high residual $\mathrm{NaNO}_{3}$ content, which is about $30 \mathrm{wt} \%$ versus almost none in $\mathrm{PW}-4 \mathrm{~b}$. The PW- $4 \mathrm{c}-7$ is unsuitable because the alumina substrate particles lost their coating of waste and sank to the bottom, finally creating large cracks because of differential shrinkage. Obviously, the particle size of $\mathrm{PW}-4 \mathrm{~b}$ is small enough (or the particles are sufficiently friable) that matrix cracking does not occur.

ADVANCED WASTE FORMS RESEARCH AND DEVELOPMENT - G. J. McCarthy, Pennsylvania State University

Work on development of two advanced waste forms continues at Pennsylvania State University's Materials Research Laboratory. The feasibility study of the isolation of $\mathrm{PW}-4 \mathrm{~b}$ in inert $\mathrm{SiO}_{2}$ matrices by hot pressing is nearing completion. Development has been started on modifying calcine formulations consisting of PW-4b plus selected oxide additions to yield a refractory, low leachability ceramic calcine (here termed "supercalcine"). A final report has been issued on matrix isolation of wastes in cement by a low temperature hot pressing process. 
Characterization of Standard PW-4b Calcine - G. J. McCarthy and C. A. Smith

A standard spray dried calcine which can be used in product development work at several sites has been prepared at PNL (identified as PW-4b-3 in Table 7, BNWL-1841). It contains a11 of the components of PW-4b except for $\mathrm{Tc}, \mathrm{Pd}, \mathrm{Rh}$ and the transuranics. It was thus necessary to update our earlier atomic concentration values for use in supercalcine development. These updated values are given in Table 11. The major differences from the earlier table ${ }^{(a)}$ are the inclusion of Ru with the resulting drop in Fe concentration and the separation of the rare earths (RE) into trivalent and $\mathrm{Ce}^{4+}$ because of the important crystal chemical differences between them under oxidizing high temperature conditions.

a. Quarterly Progress Report BNWL-1809, December 1973, p. 64.

TABLE 11. Atomic Concentrations in Standard PW-4b Calcine

\begin{tabular}{lclc}
\hline \multicolumn{1}{c}{ Element } & Atomic $\%$ & Element & Atomic $\%$ \\
\hline $\mathrm{RE}^{3+}(\mathrm{TU})(\mathrm{a})$ & 16.6 & $\mathrm{Ba}$ & 3.6 \\
$\mathrm{Ce}^{4+}$ & 11.0 & $\mathrm{U}(\mathrm{Pu})$ & 2.6 \\
$\mathrm{Mo}(\mathrm{TC})$ & 15.3 & $\mathrm{Cr}$ & 1.6 \\
$\mathrm{Zr}$ & 13.9 & $\mathrm{Te}$ & 1.6 \\
$\mathrm{Ru}$ & 7.8 & $\mathrm{Rb}$ & 1.3 \\
$\mathrm{CS}$ & 7.1 & $\mathrm{Co}(\mathrm{Rh})$ & 1.3 \\
$\mathrm{Fe}$ & 6.6 & $\mathrm{P}$ & 0.6 \\
$\mathrm{Ni}(\mathrm{Pd})$ & 4.9 & $\mathrm{Ag}$ & 0.3 \\
$\mathrm{Sr}$ & 3.6 & $\mathrm{Cd}$ & 0.3 \\
\hline
\end{tabular}

a. The trivalent rare earths $\left(R E^{3+}\right)$ are considered as a single entity because of virtually identical crystal chemical behavior. In order of abundance these are $\mathrm{Nd}, \mathrm{La}, \mathrm{Pr}, \mathrm{Y}, \mathrm{Sm}, \mathrm{Eu}, \mathrm{Gd}$. An element in parentheses indicates that part of the preceding element acts as a stand-in for this element. TU = transuranics. 
X-ray diffractograms from the new PW-4b formulations fired at 1050 and $1350^{\circ} \mathrm{C}$ have been compared to the earlier $\mathrm{x}$-ray results from a simpler $\mathrm{PW}-4 \mathrm{~b}$ formulation. As in the earlier results, the measured unit cell size indicates the major phase in each diagram to be a fluorite structure solid solution apparently consisting of $\left(\mathrm{Ce}, \mathrm{Zr} \mathrm{IO}_{2}\right.$. A second observed phase in all diagrams was a perovskite structure solid solution believed to be rich in $\mathrm{REFeO}_{3}$, based on its similarity to the previously reported pattern of $\mathrm{REFeO}_{3}$. $\mathrm{A}$ spinel solid solution phase, probably ( $\mathrm{Co}, \mathrm{Ni})(\mathrm{Fe}, \mathrm{Cr})_{2} \mathrm{O}_{4}$, observed in the old batch of fired PW-4b was missing in the new batch with its much lower iron concentration. Other possible, but as yet unconfirmed, phases were a scheelite structure solid solution, perhaps ( $\mathrm{Ba}, \mathrm{Sr}, \mathrm{Cs}, \mathrm{RE}) \mathrm{MoO}_{4}$ in all diagrams and $\mathrm{Cs}_{2} \mathrm{MoO}_{4}$ in the new $1050^{\circ} \mathrm{C}$ diagram.

Matrix Isolation of PW-4b in $\mathrm{SiO}_{2}-$ G. J. McCarthy, M. T. Davidson and E. G. Jones

In our previous studies under this heading, we found that the waste composition PW- 6 could be hot pressed into a $\mathrm{SiO}_{2}$ matrix to yield a strong, hard pellet with leachability values approaching those of "bottle glass." We attributed this enhanced densification to the partial formation of a liquid phase during processing consisting chiefly of $\mathrm{Na}_{2} \mathrm{O}-\mathrm{SiO}_{2}$. This mechanism is well known in hot pressing studies. Although PW- 6 is now abandoned due to the plans of the commercial fuel reprocessors, its use did serve to increase understanding of the mechanisms of hot pressing of wastes.

Because the waste $\mathrm{PW}-4 \mathrm{~b}$ contains relatively small amounts ${ }^{(a)}$ of the alkali oxides necessary for liquid phase sintering, high waste to matrix ratios (typically 50:50) combined with high temperatures $\left(1200^{\circ} \mathrm{C}+\right.$ ) had to be used to get adequate consolidation in hot pressing. A more suitable $1 \mathrm{PW}-4 \mathrm{~b}$ to 4 or $5 \mathrm{SiO}_{2}$ mixture will not consolidate at a "reasonable" temperature $\left(900-1200^{\circ} \mathrm{C}\right)$ due to lack of a liquid phase under processing conditions.

a. 8.1 wt\% of $\mathrm{Cs}_{2} \mathrm{O}$ and $\mathrm{Rb}_{2} \mathrm{O}$. 
An obvious solution to this problem is to add something to the matrix which will be a liquid of sufficient fluidity at processing temperatures to promote liquid phase sintering. This has been accomplished by adding two low leachability glasses to the quartz $\left(\mathrm{SiO}_{2}\right)$ matrix to produce what are termed "hybrid matrices." This addition combined with lowering the waste loading of PW-4b to the 20 to 30 weight percent range has produced very promising results.

The formulation and processing parameters which were varied included waste to matrix ratio, type of glass, glass to quartz ratio, and temperature. The two glasses used as sintering aids were an alkali-free lead borosilicate(a) and Pyrex, ${ }^{(b)}$ both purchased as -200 mesh powders. The former, a commercial low melting glass for electronic applications, had just the right viscosity properties at processing temperatures and was soon selected for all of the remaining test work. As shown in Table 12, formulations using this glass gave very hard, well consolidated products with leaching resistance approaching that of pure Pyrex glass ( $0.21 \mathrm{wt} \%$ loss in 24 hours of the Soxhlet test). The results in this table are selected from among fifteen runs to show certain compositional and processing temperature trends. In the first three the same formulation, containing only $7 \mathrm{wt} \% \mathrm{glass}$, is hot pressed at 1200 to $1000^{\circ} \mathrm{C}$. Although all resultant pellets are very much harder than stainless steel ( $>$ SS), there is a definite temperature dependence of leaching resistance, with the highest temperature giving the best result. The fourth entry shows that the temperature can be lowered to $900^{\circ} \mathrm{C}$ with very satisfactory results if more glass is used. The last three entries show that even greater leaching resistance can be obtained by decreasing waste loading from 30 to $20 \mathrm{wt} \%$. The measured density of the products varied from 2.95 to $3.13 \mathrm{~g} / \mathrm{cm}^{3}$.

Now that suitable processing conditions and formulations have been found, the most promising products will be subjected to microchemical and microstructural characterization and to tests for porosity, long-term thermal stability, thermal conductivity, etc.

a. Pemco Division, SCM Corporation, Baltimore, MD.

b. Corning Glass Works, Code 7740 . 
TABLE 12. PW-4b/Hybrid Matrix Results

\begin{tabular}{ccccccc}
\hline Run & PW-4b & $\begin{array}{c}\text { Composition, } \\
\text { Wt\% Quartz }\end{array}$ & Glass & $\begin{array}{c}\text { Hot Pressing } \\
\text { Temperature } \\
\left({ }^{\circ} \mathrm{C}\right)\end{array}$ & Hardness & $\begin{array}{c}\text { Wt\% Loss } \\
(24 \mathrm{hr})\end{array}$ \\
\hline 41 & 30 & 63 & 7 & 1200 & >>SS & 0.32 \\
43 & 30 & 63 & 7 & 1100 & >>SS & 0.53 \\
49 & 30 & 63 & 7 & 1000 & >>SS & 0.68 \\
51 & 30 & 49 & 21 & 900 & >>SS & 0.41 \\
41 & 30 & 63 & 7 & 1200 & >>SS & 0.32 \\
53 & 25 & 67.5 & 7.5 & 1200 & >>SS & 0.29 \\
55 & 20 & 72 & 8 & 1200 & >>SS & 0.22 \\
\hline
\end{tabular}

Supercalcine - G. J. McCarthy and D. E. Pfoertsch

"Supercalcine" is our term for a waste calcine to which extra components have been added to enhance key physical properties such as melting resistance and leaching resistance. This section of our work will receive the greatest emphasis overall in FY 1975.

The object in preparing this advanced waste form is to isolate waste atoms in phases which have the desirable properties. The atoms could be substituted into a phase known to have suitable properties (such as ruthenium substituted for zirconium in $\mathrm{Nd}_{2} \mathrm{Zr}_{2} \mathrm{O}_{7}$ to form $\left.\mathrm{Nd}_{2}\left(\mathrm{Zr}_{2-\mathrm{xu}_{\mathrm{x}}}\right) \mathrm{O}_{7}\right)$. Or the waste atom could form one component of a suitable compound (such as cesium in CsLaZr ${ }_{2}{ }_{6}$ ). Of course, it is important to know what phases have suitable properties. Thus a program initiated early last year to synthesize and test selected candidate phases for thermal stability and leaching resistance will be continued through this year.

This atomic-scale isolation of waste cations could be the first barrier or layer of a variety of redundant protection schemes. The supercalcine granules could then be matrix isolated in a ceramic or metal phase. 
There are two basic approaches to preparing supercalcine batches for later processing. The first is to add the extra components as liquids to the waste liquid and then to calcine the resulting liquid mixture. The second is to add the extra components as oxide powders to a calcine powder; this approach is not being studied at present. The first process is preferable from the solid state reaction standpoint because the atomic-scale mixing derived from calcining a chemically mixed batch will allow lower processing temperatures and briefer times simply because the ions have to diffuse over shorter distances to form their equilibrium phase assemblages. In addition, this waste processing would be carried out by the reprocessor on site; and if this "calcine" were then shipped to the RSSF at least it would be in a much less leachable form, and if a pressing step were included, it would also be nondispersible.

For studies on a supercalcine-wet process a simulated liquid waste was prepared containing the ten most abundant components of $P W-4 b$. This solution is designated PSUW-1. A notable feature of this waste was the removal of ruthenium for separate crystal chemical study. Although titanates and zirconates have both proved good candidates for forming thermally stable, leach resistant solid solution phases, ${ }^{(a)}$ the zirconates were chosen for the wet process. There is a widely available stable form of soluble zirconia (zirconyl nitrate), whereas violently reactive, $\mathrm{pH}$-sensitive organics must be used to obtain soluble titania. Also, in the tests performed at PNL on our samples, zirconates such as $\mathrm{SrZrO}_{3}$ and $\mathrm{RE}_{2} \mathrm{Zr}_{2} \mathrm{O}_{7}$ were found even less leachable than the corresponding titanates. The cost per mole of available zirconium is only $50 \%$ higher than titatium.

The basic approach to selection of the amount and kind of additives is to consider the amount and kind of ions in the waste and, based on a set of hypotheses on the crystal chemical behavior of each ion with the additives to add selected amounts of additives. For example, in the first set of formulations it was postulated that $\mathrm{RE}^{3+}, \mathrm{Cs}$ and $(\mathrm{Ba}+\mathrm{Sr})$ would

a. Waste Fixation Program Quarterly Progress Report, BNWL-1841, July 1974. 
form $\mathrm{RE}_{2} \mathrm{Zr}_{2} \mathrm{O}_{7}, \mathrm{Cs}_{2} \mathrm{ZrO}_{3}$ and $(\mathrm{Ba}, \mathrm{Sr}) \mathrm{ZrO}_{3}$ respectively, and the appropriate amount of zirconium was added to form these. For molybdenum the postulated phase was $\mathrm{CaMoO}_{4}$; thus calcium was also used as an additive. Since chromium and nickel were postulated to form $\mathrm{Ni}(\mathrm{Cr}, \mathrm{Fe})_{2} \mathrm{O}_{4}$, no additives were needed. Excesses of the stoichiometric amounts of calcium and zirconium were also added to study their effects on phase formation. The waste loading for the four formulations studied varied from 60 to $75 \mathrm{wt} \%$.

The liquids consisting of simulated waste $+\mathrm{ZrO}\left(\mathrm{NO}_{3}\right)_{2}+\mathrm{Ca}\left(\mathrm{NO}_{3}\right)_{2}$ were dried, calcined, pelletized and fired at 1050 and $1200^{\circ} \mathrm{C}$ for 6 to $24 \mathrm{hrs}$. As the products were only moderately consolidated, in practice sintering aids will probably be needed to give durable monolithic forms by this simple press and fire process. All three firings $\left(1050^{\circ} \mathrm{C}, 6\right.$ and $24 \mathrm{hr}$, $1200^{\circ} \mathrm{C}, 6 \mathrm{hr}$ ) gave essentially the same diffractogram. The dominant phase was a double fluorite structure, solid solution (Fss), one with a cell parameter of $a_{0} \simeq 5.32 \AA$ and $a_{0}$ second with $a_{0} \simeq 5.39 \AA$. The halved cell parameter of $\mathrm{Nd}_{2} \mathrm{Zr}_{2} \mathrm{O}_{7}$ is $5.32 \mathrm{~A}$; thus this is probably the approximate composition of one Fss phase. The second is probably a solid solution of some $\mathrm{ZrO}_{2}$ in $\mathrm{CeO}_{2}$, which shrinks the Fss cell parameter of $\mathrm{CeO}_{2}$ from $5.41 \AA$ to $5.39 \mathrm{~A}$.

The second structure type observed in all three firings was perovskite, $\mathrm{ABO}_{3}$. The phase present appeared to have a lower symmetry version of the familiar cubic structure since several reflections were split. Its nominal cel1 parameter was $\simeq 3.99 \AA$. Every ion in the PSUW- 1 formulation is a good candidate for inclusion in a perovskite structure. By this we mean that some perovskite phase is known with at least one of these ions in it. $\mathrm{CaZrO}_{3}$ has a distorted revision of this structure, and apparently the calcium promotes its formation. Thus the composition of the $3.99 \AA$ phase could conceivably be:

$$
\begin{array}{rl}
\mathrm{ABO}_{3 \pm x} & \mathrm{~A}=\mathrm{RE}^{3+}, \mathrm{Cs}, \mathrm{Sr}, \mathrm{Ba}, \mathrm{Ca} \\
\mathrm{B} & =\mathrm{Zr}, \mathrm{Fe}, \mathrm{Cr}, \mathrm{Ni}^{3+}, \mathrm{Mo}, \mathrm{Ce}^{4+}
\end{array}
$$

However, it is likely that most of the $\mathrm{RE}^{3+}$ and cerium are tied up with zirconium in the fluorite solid solution phases. 
Weight loss measurements on fully dehydrated and denitrated batches indicated a relatively small amount of oxides (probably $\mathrm{Cs}_{2} \mathrm{O}$ and $\mathrm{MoO}_{3}$ ) lost to volatilization at $1050^{\circ} \mathrm{C}$, with the remainder presumably contained in the perovskite solid solution.

In summary, the first attempts at supercalcine formulations by adding calcium and zirconium to a simulated waste have produced readily identified phase assemblages consisting of fluorite structure and perovskite structure solid solutions. Waste loading has been varied from 60 to $75 \mathrm{wt} \%$. Some, but not a large amount, of the volatile constituents of the simulated waste are lost during firing. The supercalcine must be produced in a better consolidated form before it can be tested for leachability.

With the results from the first groups of runs showing that Mo does not react with calcium to form $\mathrm{CaMoO}_{4}$ and that much of the cesium is retained in the solid solutions we can now repostulate a series of phases for new supercalcine formulations. Based on these observations, only fluorite ( $\left.(\mathrm{Ce}, \mathrm{Zr}) \mathrm{O}_{2}, \mathrm{RE}_{2} \mathrm{Zr}_{2} \mathrm{O}_{7}\right)$ and perovskite ( $(\mathrm{Ba}, \mathrm{Sr}) \mathrm{ZrO}_{3},\left(\mathrm{Cs}, \mathrm{RE}^{3+}\right) \mathrm{ZrO}_{3}, \mathrm{Cs}(\mathrm{Zr}, \mathrm{Mo}) \mathrm{O}_{3}$, $\mathrm{Sr}(\mathrm{Ni}, \mathrm{Mo}) \mathrm{O}_{3}, \mathrm{RE}(\mathrm{Fe}, \mathrm{Cr}) \mathrm{O}_{3}$, etc.) will be predicted in the hypotheses. Perovskite structure phase $\mathrm{SrZrO}_{3}$ will be used as a combination diluent and solid solution host to get waste loading down to $\simeq 40 \mathrm{wt} \%$. It is anticipated that 5 to 10 wt\% of a sintering aid will have to be added to yield a well consolidated product and that this will give a more normal 30 to $35 \mathrm{wt} \%$ waste loading.

Crystal Chemical Background for Supercalcine Formulations - G. J. McCarthy, S. A. Gallagher, C. A. Smith and R. G. Johnston

While we are proceeding to develop supercalcine formulations based on "educated guesses" backed up with crystal chemical insight and experiment observations, we would like to have specific information on the crystal chemistry and phase formation by the more troublesome constituents of PW-4b. A constituent is classified as troublesome if it is known that it will volatilize during processing or is likely to form leachable phases. Three 
prime candidates are ruthenium, cesium and tellurium. The oxides of these elements have been shown to volatilize from $\mathrm{PW}-4 \mathrm{~b}$ at elevated temperatures. In this portion of our effort we will look for refractory (i.e. thermally stable at normal processing temperatures such as $1050^{\circ} \mathrm{C}$ ) phases with high leaching resistance and with a chance of being formed from the full $\mathrm{PW}-4 \mathrm{~b}$ waste by using selected additives.

To date, an extensive bibliography on the compound formation, thermal stability and other phase relations in systems of $\mathrm{Cs}_{2} \mathrm{O}$ and one or two other oxides with good possibilities of forming durable refractory phases has been assembled. A number of titanates, zirconates, aluminosilicates, vanadates, niobates and tantalates have been identified. These will be synthesized and tested for the two important properties.

Work has also begun on studying ruthenium crystal chemistry in a similar manner. It has been found that $\mathrm{RuO}_{2}$ does not form an appreciably solid solution with $\mathrm{TiO}_{2}$ even though it is isostructural (rutile type) and the radius of $\mathrm{Ru}^{4+} \simeq \mathrm{Ti}^{4+}$. This behavior is probably due to different bonding schemes in the two phases $\left(\mathrm{TiO}_{2}\right.$ is an insulator; $\mathrm{RuO}_{2}$ is a metallic, d-band type conductor). This means that simply adding $\mathrm{TiO}_{2}$ to $\mathrm{PW}-4 \mathrm{~b}$ will not improve the properties of $\mathrm{RuO}_{2}$. Other ways of incorporating $\mathrm{RuO}_{2}$ in desirable phases must be found. Two phases currently being investigated are $\mathrm{RE}_{2} \mathrm{Ru}_{2} \mathrm{O}_{7}$ and $\mathrm{BaRuO}_{3}$. 
SAFETY AND SYSTEMS EVALUATION

SAFETY AND SYSTEMS EVALUATION - W. K. Winegardner

The purpose of the Safety-Systems Evaluation Task is to define and investigate waste management systems in relation to the containment, immobilization, and isolation of the wastes and to evaluate the risk implications of these systems. Specifically, risks of a reference system for management of high-level waste are being assessed. (a) Failure mode analysis, based on the development of fault trees for the various activities of the reference system, has resulted in the identification of myriad failure events (sequences). Work during the quarter consisted primarily of identifying methods of isolating those events (sequences) that dominate.

METHODOLOGY FOR FAULT TREE EVALUATION - T. H. Smith and P. J. Pel to Genera 1

Considerable effort has gone into a review of approaches and computer codes available for evaluating the complex fault trees which represent the various potential failure modes of the waste management system. Several approaches and various codes have been tested on the simpler fault trees. The approach selected involves approximate evaluation of the risk (not probability) represented by each cut set (potential failure sequence). This will be followed by sorting of cut sets on the basis of risk, with more extensive analysis to be directed later to those cut sets identified as being of greatest risk.

Interim Surface Storage Facility

A preliminary evaluation of the fault tree for the sealed storage cask concept (Activity 9 of the reference waste management system) has been made. The goal is to determine the high risk cut sets which need to be examined in more detail. This fault tree has fifty input events and is shown in Figure 22.

a. The reference system is described in previous reports of the series of quarterly progress reports, BNWL-1761, BNWL-1809, and BNWL-1826. 
$\frac{\pi}{\frac{\pi}{1}}$

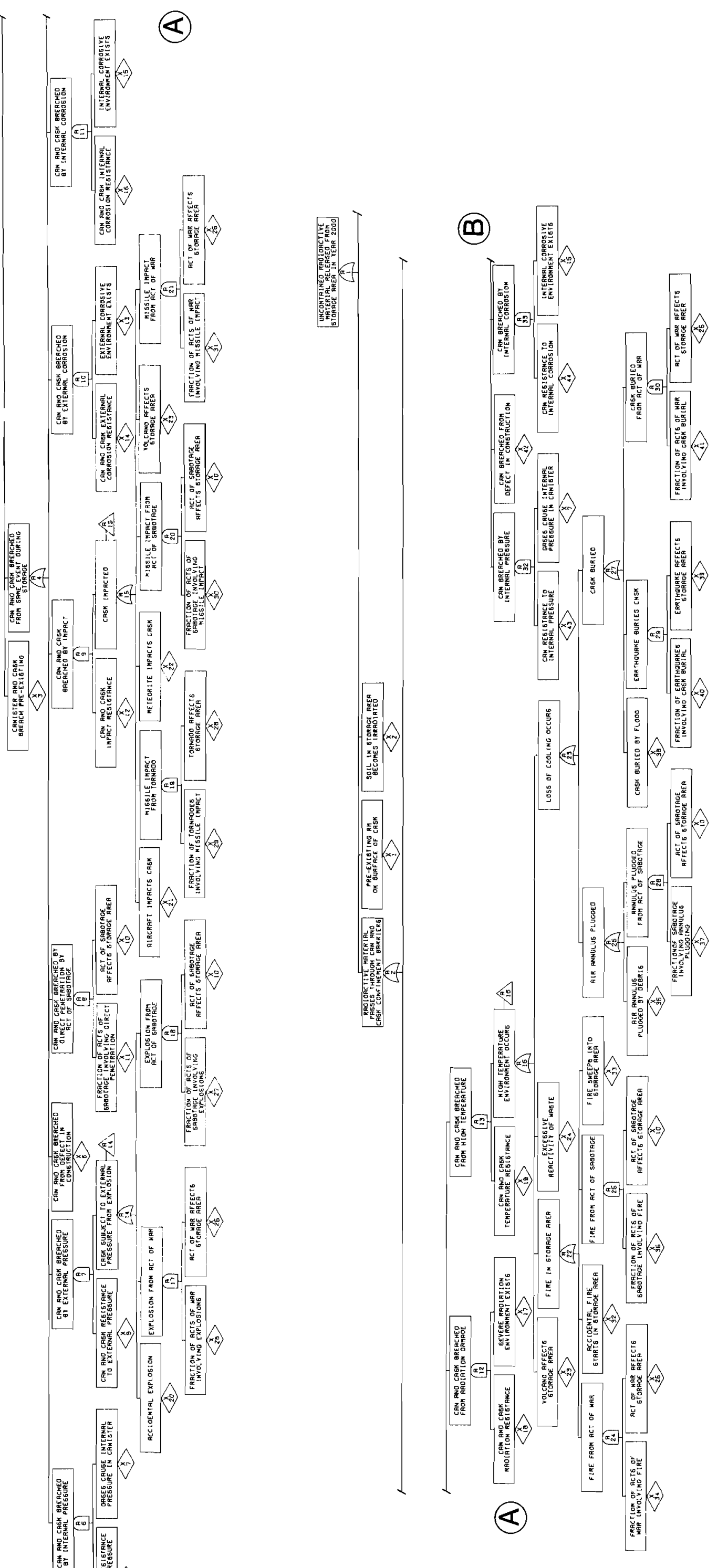

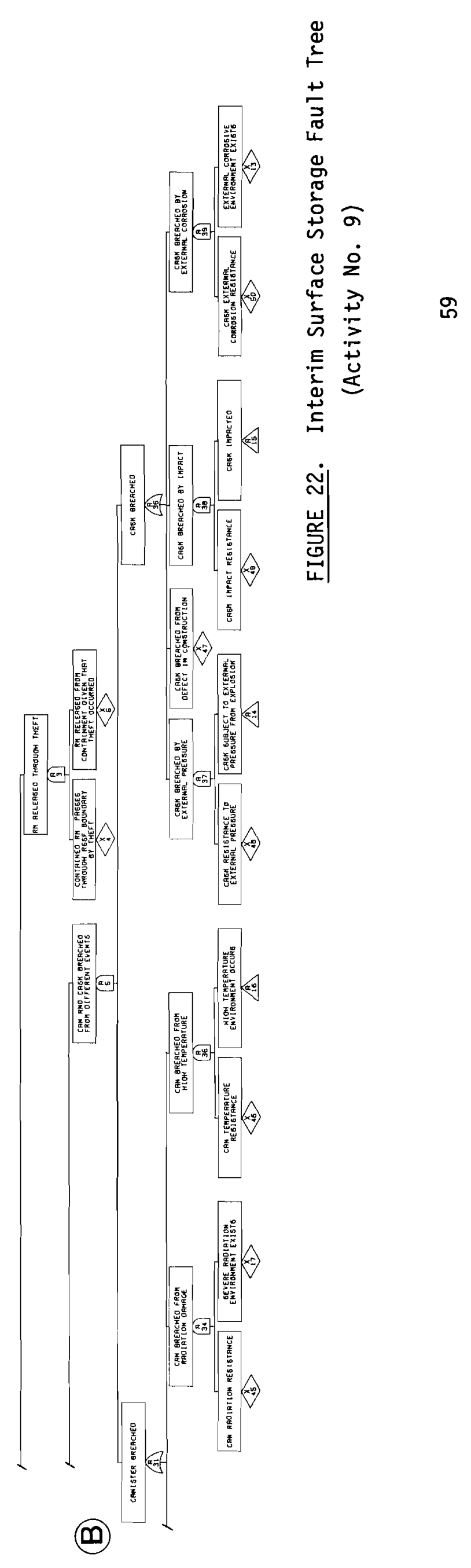


The method of evaluation used includes the following steps. $(a, b)$ The cut sets (a cut set is a mathematical expression representing a combination of component failures which must occur for system failure to occur) are hand evaluated by Boolean Algebra techniques. Rough estimates of the probabilities of each input event are made based on the potential for a given release from containment on the order of the following magnitudes: 1 milligram, 1 gram, 1 kilogram, and 1 metric ton. The resulting risk for each cut set is calculated in terms of undispersed grams per year released from containment. The cut sets are ranked on this basis with the implicit assumption that differences in the fraction of radioactive material (fines distribution) dispersed and the dispersion pathway characteristics are small compared with the calculated differences among cut sets.

The 50-event sealed cask fault tree resulted in 180 minimal cut sets ranging from one event to six events. Results thus far indicate that the one, two, and three term cut sets dominate and that the higher order cut sets can be neglected. Also, the risk from internal system failures (corrosion, defects, pressurization, radiation, etc.) is generally smaller than that from external events (explosions, aircraft crashes, sabotage, meteorites, etc.).

A ranking of the cut sets for the sealed cask fault tree has been prepared using this technique, and fifteen dominating cut sets will be analyzed in greater detail.

\section{IMPACT TESTING OF GLASS IN SIMULATED WASTE CANISTERS - T. H. Smith}

Fines analysis of the contents of the small (shortened 1/6 scale) impact canisters is essentially complete. (c) Some preliminary results

a. T. H. Smith et al, "A Methodology for Risk Analysis of Nuclear Waste Management Systems," BNWL-SA-4899, June 1974.

b. T. H. Smith, "Probabilistic Risk Analysis of Nuclear Systems," BNWL-1848, September 1974.

c. Impact testing is discussed in the two previous reports of the series of quarterly progress reports, BNWL-1826 and BNWL-1841. 
have been tabulated and are being reviewed and correlated. Initial indications are that purposeful devitrification of the glass did not have a major effect on the product impact behavior.

The high-speed film records of the drop tests of the larger (1/2 scale) impact canisters have been studied in detail. Fines analysis of the canister contents is nearing completion. 


\section{DISTRIBUTION}

No. of

Copies

\section{OFFSITE}

UNITED STATES

1 AEC Chicago Patent Group

A. A. Churm

2 AEC Directorate of Licensing

for Fuels and Materials

4915 St. Elmo Ave.

Bethesda, MD 20014

Deputy Director for Fuels

and Materials

S. H. Smiley

Chief, Technical Support Branch for Fuels and Materials

R. B. Chitwood

1 AEC Division of Biomedical and Environmental Research Earth Sciences Branch Washington, D.C. 20545

W. G. Belter

2 AEC Division of Production and Materials Management Washington, D.C. 20545

F. P. Baronowski

W. L. Lennemann

2 - AEC Division of Reactor Research and Development Washington, D.C. 20545

Assistant Director for Reactor Technology

E. E. Sinclair

Chief, Fuel Recycle Branch

W. H. McVey
No. of

Copies

7 AEC Division of Waste Management and Transportation Washington, D.C. 20545

G. H. Daly

W. K. Eister

0 . P. Gormley

A. F. Perge

F. K. Pittman

R. W. Ramsey

R. D. Walton

1 AEC Idaho Operations Office P. 0. Box 2108 Idaho Falls, ID 83401

K. K. Kennedy

1 AEC 0ak Ridge Operations Office P. 0. Box X Oak Ridge, TN 37830

E. H. Hardison

1 AEC Office of the Commissioners Washington, D.C. 20545

Tech. Asst. - Com. C. E. Larson W. H. Beach

1 AEC Savannah River Operations Office P. 0. Box A Aiken, SC 29801

P. D. Fairchild

212 AEC Technical Information Center

5 Allied Chemical Corporation 550 - 2nd Street Idaho Fal1s, ID 83401

J. A. Buckham

B. R. Dickey

E. W. Rhodes

C. M. Slansky

B. R. Wheeler 
No. of

Copies

3 Allied-Gulf Nuclear Services P. 0. Box 847

Barnwel1, SC 29812

B. M. Legler

G. R. Bray

A. Schneider

1 Argonne National Laboratory 9700 South Cass Ave. Argonne, IL 60439

$$
\text { R. C. Voge } 1
$$

1 Bechtel Corporation

50 Beale Street

San Francisco, CA 94119

1 C-E Refractories

Box 828

Valley Forge, PA 19482

Alfred W. Allen

1 Ceramic Engineering

University of I1linois

Urbana, IL 61801

Dr. Dennis 0'Boyle

1 Combustion Engineering, Inc. Combustion Division

Windsor, CT 06095

Jack Parry

1 Corning Glass Works

Technical Staffs Division

Corning, NY 14830

M. G. Britton

1 Desert Research Institute University of Nevada System Reno, NV 89507

P. Senske
No. of

Copies

1 Dow Chemical Company (AEC)

Rocky Flats Division

P. 0. Box 888

Golden, C0 80401

D. L. Ziegler

4 duPont Company, Aiken (AEC)

E. I. duPont DeNemours and Co.

Savannah River Laboratory

Aiken, SC 29801

C. H. Ice

A. S. Jennings

L. H. Meyer

R. W. Wallace

1 duPont Company, Wilmington (AEC) E. I. duPont DeNemours and Co. Wilmington, DE 19898

A. A. Johnson

2 Environmental Protection Agency

Parklawn Building

5600 Fishers Lane

Rockville, MD 20852

C. G. Meyers

1 Environmental Protection Agency P. 0. Box 15027

Las Vegas, NV 89114

B. Mann

1 Environmental Protection Agency 5555 Ridge Ave. Cincinnati, OH 45213

R. E. Landreth

1 E. R. Johnson Associated, Inc. Suite 317 91017 th N.W.

Washington, D.C. 20006

J. P. McBride 
BNWL- 1871

No. of

Copies

1 Genera 1 Electric Company

175 Curtner Ave.

(M/C 160)

San Jose, CA 95125

R. G. Barnes

1 General Electric Company

Midwest Fuel Recovery PTant

Route 1, Box 219-B

Morris, IL 60450

R. Lambert

2 Genera 1 Electric Company

Vallecitos Nuclear Center

Vallecitos Road

Pleasanton, CA 94566

W. H. Reas

1 Gibbs and Hi11, Inc.

393 Seventh Ave.

New York, NY 10001

P. P. DeRienzo

3 General Atomic Co.

P. 0. Box 81608

San Diego, CA 92138

L. H. Brooks

J. J. Shefcik

M. E. Spaeth

1 Los Alamos Scient ific Laboratory $(A E C)$

P. 0. Box 1663

Los Alamos, NM 87544

C. W. Christenson

1 National Lead Company

111 Broadway

New York, NY 10006

Stephen Brown
No. of

Copies

1 National Academy of Sciences

Corrmittee of Radioactive Waste

Management

2101 Constitution Ave. NW

Washington, D.C. 20418

D. Cyrus Klingsberg,

Technical Secretary

2 Nuclear Fuel Services, Inc.

P. 0. Box 124

West Valley, NY 14171

J. P. Duckworth,

Plant Manager

6000 Executive B1vd., Suite 600

Rockville, MD 20852

E. D. North, Director of

Technical Administration

1 Nuclear Safety Associates

5101 River Rd.

Bethesda, MD 20016

W. A. Rodger

1 NYS Atomic and Space

Development Authority

230 Park Ave., Room 2425

New York, NY 10017

J. G. Cline, General Manager

1 Numen

609 Warren Ave.

Apo110, PA 15613

C. R. Woods

4 Oak Ridge National Laboratory (AEC)

Centra] Research Library,

Document Reference Section

Central Research Library, ORNL

Laboratory Records Dept., ORNL

Laboratory Records Dept., ORNL-RC

P. 0. Box X

Oak Ridge, TN 37830 
No. of

Copies

1 Penberthy Electrome $7 t$ 631 S. 96th Street Seattle, WA 98108

L. Penberthy

1 Pennsylvania State University Materials Research Laboratory University Park, PA 16802

G. J. McCarthy

3 Sandia Laboratories A1buquerque, NM 87107

R. L. Hagengruber

R. W. Lynch

A. C. Zuppero

4 Union Carbide Corporation (ORNL) Chemica T Technotogy Division P. 0. Box $Y$

Oak Ridge, TN 37830

J. 0. Blomeke

A. L. Boch

F. Gera

H. W. Godbee

1 University of California, Los Angeles

6532 Boelter Hall

Los Angeles, CA 90024

John D. Mackenzie

FORE IGN

1 Atomic Energy of Canada Ltd. W.N.R.E. Pinawa, Mani toba, ROE ILO

CANADA

$$
\text { P. J. Dyne }
$$

1 Atomic Energy of Canada Ltd. Chalk River, Ontario CANADA

J. A. Morrison
No. of

Copies

1 Atomic Energy of Canada Ltd. Sheridan Park, Ontario CANADA

W. M. Campbe 11

1 EURATOM

Health Physics Division

29, Rue Aldringer

Luxembourg, BELGIUM

Rene Amavis

1 Studiecentrum voor Kernenergie (Mol)

SCK, CEN

Boeretang, 200

2400 Mo 1. BELGIUM

P. Dejonghe

1 Atomic Energy Research

Establishment

Harwe 1], Didcot, Berks.

ENGLAND

K. D. B. Johnson

1 United Kingdom Atomic Energy

Authority

RisTey, ENGLAND

D. W. Clelland

2 Centre de Marcoule

B. P. 106

30 - Bagnols S/Ceze

FRANCE

R. Bonniaud

3 Centre d'Etudes Nucleaires

de Fontenay-aux-Roses

Boite Postale 6

92 - Fontenay-aux-Roses

FRANCE

P. J. Regnaut

J. Sauteron

Y. J. Sousselier 
No. of

Copies

1 Bundesministerium für Bildung

und Wessenschaft

D53 Bonn 12

Postfach 120124

GERMANY

R. P. Rand 1

1 Gesellschaft für Strahlen und Umwe11forschung

Institut für Tieflogerung

3392 Clausthal - Zellerfeld

Bornhardstr. 22

GERMANY

K. Kühn

1 Hahn-Meitner-Institut

1 Berlin 39

Glienickerstr. 100

GERMANY

Hans W. Levi

2 Institut für Chemische

Technologie

Kernforschungsanloge Julich GmbH

D517 Julich

Postfach 365

GERMANY

E. R. Merz

K. H. Rattay

1 MGH/GWK/Wiederacifurbeitung San 1age/WAK

Karlsruhe, GERMANY

W. A. Isse 1

2 Nuclear Research Center

Waste Management Dept.

D75 Karlsruhe

Weberstr. 5

GERMANY

H. Krause
No. of

Copies

1 NUKEM

6450 Hanau

P. 0. Box 869

W. GERMANY

Dr. Hartmut Witte

3 CNEN

Directtore of Programma Eurex

Del CNEN

Saluggia "Vercel1i," ITALY

Giacomo Calleri

Laboratorio di Ingegneria

Sanitaria

Via Anguillarese $\mathrm{km} 1+300$

Roma, ITALY

Willy Bocola

Viale Regina Margherita 125

00198 Roma, Italy

Ferruccio Gera

1 Bhabha Atomic Research Centre

Organic Waste Laboratory

Plutonium Plant Site

Trombay, Bombay,

INDIA

Keshava Chandra

2 Bhabha Atomic Research Centre Waste Treatment Division Trombay, Bombay, INDIA

N. S. Sunder Rajan

K. T. Thomas

1 India Atomic Energy Establishment

Waste Treatment Plant and

Decontamination Center

Bombay 85, INDIA

Victor Amalraj,

Plant Superintendent 
BNWL- 1871

No. of

Copies

2 International Atomic Energy Agency Kartner Ring 11

P. 0. Box 590

A-1011, Vienna, AUSTRIA

1 Dr. H. F. Ramdohr

c/o Friedrich Uhde GmbH

46 Durtmund

Deggingstr. 10-12

GERMANY

\section{ONSITE}

1 AEC/RL Patent Attorney

R. M. Poteat

3 AEC Richland Operations Office Production and Waste Management Programs Division

0. J. Elgert (2)

Research and Development

Programs Division

B. J. Melton

1 AEC/RL Environmental, Safety and Technical Services Division

P. G. Holsted

12 Atlantic Richfield Hanford Co. P. 0. Box 250 Federal Building

Richland, WA 99352

H. Babad

L. E. Browne 11

M. H. Campbel1

R. E. Isaacson

D. C. Nelson

R. C. Rowles

H. P. Shaw

W. W. Shultz/M. J. Kupfer

A. E. Smith

M. J. Szulinski

R. J. Thompson

J. H. Warren

D. D. Wodrich

File Copy
No. of

Copies

2 Exxon

Richland, WA 99352

S. J. Beard

L. T. Lakey

2 United Nuclear Industries, Inc. Richland, WA 99352

2 Westinghouse Hanford Company Richland, WA 99352

C. R. Cooley

G. L. Richardson

48 Battelle-Northwest

E. L. Alpen

R. J. Bashor

J. L. Bates

W. J. Bjorkland

H. T. Blair

W. F. Bonner

D. J. Bradley

N. E. Carter

C. C. Chapman

T. D. Chikalla

R. B. Dakan

G. M. Dalen

R. D. Dierks

J. W. Finnigan

T. A. Golding

J. N. Hartley

G. Jansen

J. D. Kaser

J. L. McElroy (10)

J. E. Mende 1

D. F. Newman

P. J. Pelto

A. M. Platt

J. Posakony

W. A. Ross

K. J. Schneider

D. H. Siemens

I. H. Smith

W. H. Swift

R. P. Turcotte

L. D. Williams/R. J. Hall

W. K. Winegardner

Technical Information (5)

Technical Publications (3) 